\title{
A mouse cdc25 homolog is differentially and developmentally expressed
}

\author{
Akira Kakizuka, ${ }^{1}$ Byron Sebastian, ${ }^{2,3}$ Uwe Borgmeyer, ${ }^{1}$ Irm Hermans-Borgmeyer, ${ }^{1}$ Jack Bolado, ${ }^{1,4}$ \\ Tony Hunter, ${ }^{2}$ Merl F. Hoekstra, ${ }^{2}$ and Ronald M. Evans ${ }^{1,4}$ \\ ${ }^{1}$ Gene Expression Laboratory, ${ }^{4}$ Howard Hughes Medical Institute, and ${ }^{2}$ Molecular Biology and Virology Laboratory, The Salk \\ Institute for Biological Studies, La Jolla, California 92037 USA; ${ }^{3}$ Department of Biology, University of California, San Diego, \\ La Jolla, California 92093 USA
}

The timing and activation of the $\mathrm{p} 34^{\mathrm{cdc} 2}$ kinase in mammals is associated with dephosphorylation of phosphotyrosine and phosphothreonine residues on the $\mathrm{p} 34^{\text {cdc2 }}$ kinase. For fission yeast, the timing of mitosis is regulated by cyclic accumulation of cdc25, which promotes dephosphorylation of $\mathbf{p} 34^{\text {cde2 } 2}$ and concomitant protein kinase activation. We report the identification and characterization of a structural and functional mouse homolog, Cdc25M2, of the cdc25 phosphatase. Cdc25M2 shows high sequence identity to the previously reported human homolog $c d c 25 \mathrm{Hu} 2$. Cdc25M2 can functionally complement for a Schizosaccharomyces pombe cdc25 $5^{\text {ts }}$ mutation, and when expressed in Escherichia coli and purified, Cdc25M2 is an active phosphatase. cdc25M2 mRNA shows variation in expression in different tissues in the mouse embryo and is expressed in a developmental and cell-cycle-dependent fashion. We suggest that the expression and accumulation of the cdc25 mitotic inducer may play a critical role in the regulation of mouse development.

[Key Words: cdc25M2; mouse; developmental expression; cell-cycle-dependent expression; phosphatase]

Received January 10, 1992; revised version accepted February 13, 1992.

Chromosomal replication in $\mathrm{S}$ phase and chromosome segregation in $M$ phase are the two major cell cycle events that are conserved among eukaryotic cells. Central to these events is a group of regulatory gene products that control the passage through $S$ phase and mitosis. These regulators act as intrinsic controls during cell cycle progression and respond to extracellular conditions and signals to drive the cell cycle. They include a number of protein kinases and phosphatases that were defined initially by genetic studies in budding and fission yeast (Reed 1980; Nurse and Bissett 1981) and by biochemical studies in Xenopus and sea urchin (Masui and Markert 1971; Evans et al. 1983). Of particular interest is a universal control that regulates $\mathrm{M}$-phase onset (for review, see Nurse 1990), and central to this control is the conserved $\mathrm{p} 34^{\mathrm{cdc} 2}$ protein kinase. Activation of $\mathrm{p} 34^{\mathrm{cdc} 2}$ induces $M$ phase, and high p34 ${ }^{\text {cdc2 }}$ kinase activity maintains the cell in M-phase state. A second component of this cell cycle progression control is a family of proteins called cyclins. Cyclins are regulatory components of the cdc2 family of protein kinases, and cyclin B is required for $\mathrm{p} 34^{\text {cdc2 }}$ kinase activation. There are various types of cyclins (for review, see Pines and Hunter 1990, 1991; Hunter and Pines 1991; Reed 1991) that appear to have roles at different points in the cell cycle.

In fission yeast, the cell cycle timing of M-phase entry is governed by two mitotic inducer genes, cdc25 $5^{+}$and cdr $1^{+} /$nim $1^{+}$(Russell and Nurse 1986; Feilotter et al.
1991), and two mitotic inhibitor genes, wee $1^{+}$and mik1 ${ }^{+}$(Russell and Nurse 1987; Lundgren et al. 1991). The products of these genes act together to regulate the function of $\mathrm{p} 34^{\mathrm{cdc} 2}$ for the initiation of $M$ phase. The $c d r 1^{+} / \mathrm{nim} 1^{+}$, wee $1^{+}$, and $m i k 1^{+}$genes encode protein kinases, whereas the $c d c 25^{+}$gene product promotes dephosphorylation of $\mathrm{p} 34^{\mathrm{cdc} 2}$. In wild-type Schizosaccharomyces pombe cells, the $c d c 25^{+}$mitotic inducer is required for entry into mitosis, for $\mathrm{p} 34^{\mathrm{cdc} 2}$ dephosphorylation and for $\mathrm{p} 34^{\mathrm{cdc} 2}$ protein kinase activation. It appears that the level of $c d c 25^{+}$expression in fission yeast is rate limiting for $M$-phase entry in S. pombe. Incremental increases in $c d c 25^{+}$gene dosage cause a decrease in cell size at mitosis, and the levels of cdc25 $5^{+}$mRNA and protein increase as cells approach mitosis (Russell and Nurse 1986). For fission yeast, these data suggest that the timing of mitosis is regulated by cyclic accumulation of cdc25 and that cdc25 regulates dephosphorylation of p34 $4^{\mathrm{cdc} 2}$ and subsequent protein kinase activation.

The mitotic activity of fission yeast $c d c 25^{+}$is highly conserved among eukaryotes. First, in the budding yeast Saccharomyces cerevisiae, a mitotic inducer gene called MIH1 can complement $S$. pombe temperature-conditional $c d c 25^{-}$mutants (Russell et al. 1989). Unlike $S$. pombe, the $S$. cerevisiae MIH1 gene is not essential and can be mutated without causing a significant growth defect. However, when the $S$. pombe wee $1^{+}$protein kinase is expressed in an $S$. cerevisiae mih1 mutant, the trans- 
genic yeast strain arrests in $\mathrm{G}_{2}-\mathrm{M}$ phase. Second, in Drosophila, a mitotic activator called string (stg) has been described that, like $c d c 25$, encodes an essential function (Edgar and O'Farrell 1990).

Human homologs (CDC25Hs1 and CDC25Hu2) of fission yeast $c d c 25$ have been described previously (Sadhu et al. 1990; Nagata et al. 1991). The CDC25Hs1 cDNA was identified through a polymerase chain reaction (PCR)-based strategy that amplified a region of the human gene that is conserved with the budding yeast and Drosophila cdc25 proteins, whereas $C D C 25 \mathrm{Hu} 2$ was isolated by its ability to functionally complement a $S$. pombe $c d c 25^{t s}$ mutant. Similarly, CDC25Hs1 also complements a $c d c 25^{t s}$ mutant. Antisera raised against CDC25Hs 1 and microinjected into HeLa cells result in $\mathrm{G}_{2}$-phase arrest (Millar et al. 1991). This suggests that cdc25 may be an important regulator of the onset of mitosis in mammalian cells.

There is increasing evidence from vertebrate systems that, as in fission yeast, the onset of mitosis is controlled by the $\mathrm{p} 34^{\mathrm{cdc} 2} /$ cyclin B complex. Once cyclin B associates with $\operatorname{cdc} 2$ in $G_{2}$ phase, cdc2 is phosphorylated on tyrosine-15 (Y-15) and threonine-14 (T-14), which are dephosphorylated as cells enter mitosis. These residues are within the predicted nucleotide-binding region of cdc2. Mutation of these sites suggests that phosphorylation of Y-15 and T-14 inhibit $\mathrm{p} 34^{\mathrm{cdc} 2} /$ cyclin B kinase activity (Krek and Nigg 1991; Norbury et al. 1991). Purified bacterially expressed cdc25 has been shown to activate $\mathrm{p} 34^{\mathrm{cdc} 2} /$ cyclin $\mathrm{B}$ in vitro by dephosphorylating cdc2 (Gautier et al. 1991; Kumagai and Dunphy 1991; Strausfeld et al. 1991). These observations suggest that the activity of the $\mathrm{p} 34^{\mathrm{cdc} 2} /$ cyclin $\mathrm{B}$ kinase is negatively regulated by phosphorylation at Y-15 and T-14.

To investigate further the nature of mitotic control in mammalian cells, we report here the identification and isolation of a $c d c 25$ homolog from mouse. The product of the mouse cdc25 homolog, which we call Cdc25M2 because of its similarity to $\mathrm{CDC} 25 \mathrm{Hu} 2$, rescues a fission yeast $c d c 25^{t s}$ mutant and can dephosphorylate $p$-nitrophenyl phosphate ( $p$-NPP), indicating conservation of structure and function in the cdc25 family. We also report that this mouse cdc25 homolog shows variation in expression in different tissues in the mouse embryo and is expressed in a developmental and cell cycle-dependent fashion, indicating that the expression and accumulation of the cdc25 mitotic inducer may play a critical role in the regulation of development.

\section{Results}

\section{Isolation of the mouse cdc $25 \mathrm{cDNA}$}

Protein sequence comparisons of the known cdc25 homologs revealed a highly conserved carboxy-terminal region of $\sim 150$ amino acids. To isolate a mouse $c d c 25$ cDNA, we used the Drosophila stg cDNA encoding these amino acids as a probe for low-stringency hybridization. The longest cDNA (clone 6, $2.9 \mathrm{~kb}$, Fig. 1) obtained from a mouse P19 teratocarcinoma cell cDNA library contained a $1.7-\mathrm{kb}$ open reading frame that potentially encodes a 576-amino-acid protein. Another related clone (clone 4) contained an insert encoding a stop codon upstream of methionine 200 of clone 6 . This insert is 76 nucleotides long and occurs after nucleotide 560 in clone 6. PCR was used in an attempt to detect the presence of this insert in P19 mRNA. A single detectable fragment of the size predicted by clone 6 was produced (data not shown). This analysis suggests that clone 6 is the more physiologically relevant form of cdc25M2 mRNA in P19 cells.

The protein encoded by $c d c 25 M 2$ mRNA shares a conserved carboxy-terminal region with the other known cdc25 proteins. Most of the homology between Cdc25M2 and all other cdc25-like gene products is located in a region in Cdc25M2 that starts at amino acid position 388 and extends for 155 amino acids to residue 542 (Figs. 1 and 2). Within this region of homology, Cdc25M2 shows greatest identity to the human CDC25Hu2 $(91 \%)$ and least identity to the S. cerevisiae MIH1 protein $(30 \%)$.

The highest region of homology within the five cdc 25 proteins can be found between residues 433 and 453 and 475 and 495 in the Cdc25M2 protein. These regions contain the cdc 25 shared motifs of IXDCRYPYEYXGGHIXXAVNL and KRXILXFHCEFSSERGPXMXR. Because these motifs are so highly conserved between species (81\% for Cdc25M2), they might represent the active functional region in all of these proteins. For example, the HCEFSSER motif is similar to the invariant HCXAGXXR motif (Cool et al. 1989; Guan et al. 1990, 1991) surrounding the active site of various protein tyrosine phosphatases (PTPases) and is essential to cdc25 activity (Dunphy and Kumagai 1991; Gautier et al. 1991).

Unlike any of the other $c d c 25$ homologs, Cdc25M2 shows substantial amino acid identity to $\mathrm{CDC} 25 \mathrm{Hu} 2$ throughout the entire protein (Figs. 2 and 3). The overall identity between Cdc25M2 and CDC25Hsl and $\mathrm{Hu} 2$ is $37 \%$ and $81 \%$, respectively. Outside the conserved catalytic domain of the cdc25 family, Cdc25M2 is most closely related to $\mathrm{CDC} 25 \mathrm{Hu} 2(76 \%)$ and shows little identity to $\mathrm{CDC} 25 \mathrm{Hs} 1(20 \%)$ (Fig. 2). It is for this reason that we have named this mouse homolog of $c d c 25$ cdc25M2.

cdc25M2 is a functional homolog of S. pombe cdc25

To investigate whether the mouse $c d c 25 M 2$ gene and $S$. pombe $c d c 25^{+}$gene have similar roles in mitotic control, we determined whether cdc25M2 could rescue a fission yeast temperature-sensitive $c d c 25^{-}$mutation. The $c d c 25 M 2$ cDNA was isolated and ligated into a LEU2, $2 \mu$ origin-based plasmid containing the SV40 early promoter. The resulting plasmid as well as the parental plasmid were transformed into a $S$. pombe cdc2522 leu1-32 strain. Transformants were isolated and examined for their ability to complement for the temperature-sensitive $c d c 25-22$ lesion. The mouse $c d c 25 \mathrm{M} 2$ cDNA allowed cdc25-22 cells to form colonies at $35^{\circ} \mathrm{C}$, 
1 TCCCCTCACCCCAGGCTCACTCTCGGAGCTGAGCCAGCTGGGTCGGCGTCTGCTGGCCGCTGTACTGTGGCCCTCTAGCTAGCCTTTGCC 91 CGCCCCGCCACGATGGAGGTACCCCTGCAGAAGTCTGCGCCGGGTTCAGCTCTCAGTCCTGCCCGCGTGCTGGGTGGCATTCAGCGGCCG

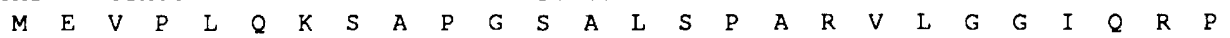

181 CGCCACCTCTCGGTCTTTGAGTTTGAGTCTGATGGCTTCCTGGGGTCTCCGGAGCCTACAGCTTCCTCCTCTCCGGTTACCACTCTTACA $\begin{array}{llllllllllllllllllllllllllllll}R & H & L & S & V & F & E & F & E & S & D & G & F & L & G & S & P & E & P & T & A & S & S & S & P & V & T & T & L & T\end{array}$

271 CAGACCATGCACAACCTCGCTGGGCTCGGCAGTGAGCCTCCAAAAGCTCAAGTAGGAAGCCTGTCGTTCCAGAACAGGCTGGCAGACCTA $\begin{array}{llllllllllllllllllllllllllllllllllll}Q & T & M & H & N & L & A & G & L & G & S & E & P & P & K & A & Q & V & G & S & L & S & F & Q & N & R & L & A & D & L\end{array}$

361 TCCCTGTCCAGGCGCACCTCTGAGTGCTCCCTGTCATCTGAGTCCTCAGAATCTTCGGATGCAGGTCTGTGCATGGACTCCCCCAGCCCT $\begin{array}{lllllllllllllllllllllllllllllllllll}S & L & S & R & R & T & S & E & C & S & L & S & S & E & S & S & E & S & S & D & A & G & L & C & M & D & S & P & S & P\end{array}$

451 GTGGACCCGCAGATGGCAGAGCGCACGTTTGAACAGGCCATTCAGGCAGCCAGTCGGGTCATTCAAAATGAGCAGTTTACCATAAAACGC $\begin{array}{llllllllllllllllllllllllllllllllll}V & D & P & Q & M & A & E & R & T & F & E & Q & A & I & Q & A & A & S & R & V & I & Q & N & E & Q & F & T & I & K & R\end{array}$

541 TTCCGATCCTTACCAGTGAGGCTGCTGGAACACAGTCCGGTGCTGCAGAGCATCACCAACTCCCGAGCACTGGACAGCTGGAGGAAAACT $\begin{array}{llllllllllllllllllllllllllllllll}F & R & S & L & P & V & R & L & L & E & H & S & P & V & L & Q & S & I & T & N & S & R & A & L & D & S & W & R & K & T\end{array}$

631 GAAGCAGGCTACCGAGCCGCCGCCAATAGTCCTGGGGAGGACAAAGAGAATGATGGATATATCTTCAAGATGCCACAGGAGCTCCCTCAT $\begin{array}{lllllllllllllllllllllllllllllllll}E & A & G & Y & R & A & A & A & N & S & P & G & E & D & K & E & N & D & G & Y & I & F & K & M & P & Q & E & L & P & H\end{array}$

721 TCCAGCTCTGCCCAAGCTTTGGCAGAATGGGTCAGCCGCAGACAGGCCTTTACCCAGAGGCCCAGCTCAGCCCCTGACTTGATGTGTCTT $\begin{array}{llllllllllllllllllllllllllllllllll}S & S & S & A & Q & A & L & A & E & W & V & S & R & R & Q & A & F & T & Q & R & P & S & S & A & P & D & L & M & C & L\end{array}$

811 ACCACTGAGTGGAAGATGGAAGTAGAGGAGCTGAGCCCGGTGGCACAGTCTTCTTCCTTGACTCCTGTCGAAAGGGCTTCTGAAGAAGAT

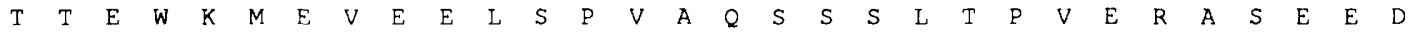

901 GACGGATTTGTGGACATCCTGGAGAGTGATTTAAAGGATGACGAGAAGGTCCCCGCGGGCATGGAGAACCTCATTAGTGCCCCACTGGTC $\begin{array}{llllllllllllllllllllllllllllllllllll}D & G & F & V & D & I & L & E & S & D & L & K & D & D & E & K & V & P & A & G & M & E & N & L & I & S & A & P & L & V\end{array}$

991 AAAAAGCTGGATAAGGAAGAGGAACAGGATCTCATCATGTTCAGCAAGTGCCAGAGGCTCTTCCGCTCCCCATCCATGCCATGCAGTGTG $\begin{array}{llllllllllllllllllllllllllllll}K & K & L & D & K & E & E & E & Q & D & L & I & M & F & S & K & C & Q & R & L & F & R & S & P & S & M & P & C & S & V\end{array}$

1081 ATCCGACCCATCCTCAAGAGGCTAGAGCGGCCCCAGGACCGGGATGTGCCTGTCCAGAGCAAGCGCAGGAAAAGTGTGACACCCCTGGAA $\begin{array}{llllllllllllllllllllllllllllllll}I & R & P & I & L & K & R & L & E & R & P & Q & D & R & D & V & P & V & Q & S & K & R & R & K & S & V & T & P & L & E\end{array}$

1171 GAGCAGCAGCTTGAAGAACCTAAGGCCCGTGTC'TTCGCTCAAAGTCGCTGTGTCATGAGATTGAGAACATCCTGGATAGTGACCACCGT $\begin{array}{llllllllllllllllllllllllllllllllll}E & Q & Q & L & E & E & P & K & A & R & V & F & R & S & K & S & L & C & H & E & I & E & N & I & L & D & S & D & H & R\end{array}$

1261 GGACTGATCGGAGATTACTCTAAGGCCTTCCTCCTGCAGACCGTGGATGGCAAACACCAAGACCTTAAGTACATCTCACCAGAAACTATO

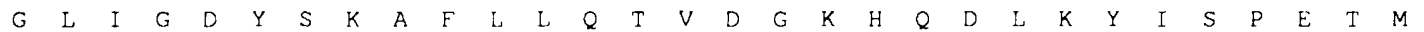

1351 GTGGCCCTGTTAACAGGCAAGTTCAGCAACATCGTGGAGAAATTTGTCATTGTGGACTGCAGATACCCCTATGAGTATGAAGGCGGGCAT $\begin{array}{llllllllllllllllllllllllllllllllll}V & A & L & L & T & G & K & F & S & N & I & V & E & K & F & V & I & V & D & C & R & Y & P & Y & E & Y & E & G & G & H\end{array}$

1441 ATCAAGAATGCTGTGAACCTGCCCCTGGAACGGGATGC'TGAGACCTTTCTGCTGCAGCGTCCCATCATGCCTTGTAGCCTGGACAAGAGA $\begin{array}{llllllllllllllllllllllllllllll}I & K & N & A & V & N & L & P & \text { J } & E & \mathrm{R} & \mathrm{D} & A & \mathrm{E} & \mathrm{T} & \mathrm{F} & \mathrm{L} & \mathrm{I} & \mathrm{Q} & \mathrm{R} & \mathrm{P} & \mathrm{I} & \mathrm{M} & \mathrm{P} & \mathrm{C} & \mathrm{S} & \mathrm{L} & \mathrm{D} & K & \mathrm{R}\end{array}$

1531 ATCATCCTCATTTTCCACTCTGAATTCTCGTCTGAGCGTGGACCACGAATGTGCCGCTTCATCAGGGAACGGGACCGTGCAGCTAACGAC $\begin{array}{llllllllllllllllllllllllllllllllll}I & I & L & I & F & H & C & F & F & S & S & E & R & G & P & R & M & C & R & F & I & R & E & R & D & R & A & A & N & D\end{array}$

1621 TACCCCAGCCTGTACTACCCGGAGATGTACATCCTCAAAGGCGGCTACAAGGAGTTCTTCCCACAGCATCCGAACTTTTGTGAGCCCCAG $\begin{array}{llllllllllllllllllllllllllllllll}Y & P & S & L & Y & Y & P & F & M & Y & I & L & K & G & G & Y & K & E & F & F & P & Q & H & P & N & E & C & E & P & Q\end{array}$

1711 GACTACCGACCCATGAACCACGAGGCTTTCAGGGATGAGCTGAGGAACTTTCGCCTTAAGACTCGCAGCTGGGCTGGGGAACGGAGCAGG $\begin{array}{lllllllllllllllllllllllllllllllllll}D & Y & R & P & M & N & H & E & A & F & R & D & E & L & R & N & F & R & L & K & T & R & S & W & A & G & E & R & S & R\end{array}$

1801 AGGGAACTTTGTAGCAGGCTGCAAGACCAGTGTGATGAGCCTGCTGCCATCCTTACCTCGTGAGGTTGGGAGCCAGTGGGTCCCATGG $R \quad E \quad L \quad C \quad S$ R L $Q$ D $D$ Q *

1891 GCCTGTGAGGCCACCTACCTTATAGAGGCC'TAGGTGCTATAGGGGTTGGGGGCATGGTGTGGTG'TCACATCTGTCTGCCCCTGTCCTC

1981 AATTTTCCTGTCTCACTCCACTTATT'T'TCTGTATCTTGGTACTGGTCCCAGCTTAAAGAGCTGAACCTGAGGGTGCATGCCAGCTGAGGA 2071 GAAGTCTGTTGTGTTCAGTGGGAGTCCTTTACAGTCTTTT'TTCCTTGTTTGTGTTGACTCTTTCTCTTCCCGCTTTTTGGGGAGAGCCT 2161 CAGCCCCGTTAGGATGGCACAGTAGCTTC'TTGCATGGCCTGGATGCAGGATCCTACTCTGCTACACAGGGC'TGTGTCTACTCTCCTCTCC 2251 TGGCCACTGGCATAGACTTATGCTCTCCATTGGAAGCATAAGTGGCTTTCTCTTCTGTTGTAGTCTTACC'TGTAGCTTTCATTTTTTTGT 2341 CTGTCTGACACACTGACCGCTGGGGAGGCTTCCTTGTACAGCTTGGGGCTAGAGATTCAAATATCACTTACTCGTTAGGCCTGGCTTTTO 2431 TTAGCCCAGAAAGGGATCTTGCCCTTTAAGACCCCCAGGGCTAGAGGGAAGGCCTGACTCAGGAGCCTCTGGGAGCCCCATCCTCACTAC 2521 TGTGAACCCCAGAGCCTCGCTGGTCAGCACTTGCTGCTGGGCAATGGACCAGTCACCGAGCTTTGCTGTTTGATCCTTCTCTGCCCTTCC 2611 CTGTTT'TCCTTTCTATATCTGGCCCAGAAGACCTCT'TCTATGTGTGGTT'TTTC'TG'TGTTGTACTAGTGACTTGAGTCTAGGCCCTTTGTT 2701 GCATGGTCATGGATGCACAGTGCCTTATATACATGTATGCACACAAACCGGGTCCAAGTATTTTGGTAAGCATGATGGCCTATGGCAGGA 2791 GTGTGTGTGTGCGCGTGTGAACAAAG'TCATTACACTTAGTGTTTGGAAATGTTAAAGAAGCATTGTTATTATGGGGAGGGGGGAGCAACC 2881 TCTGGGTTCAGAATCTACATATGCTGGAAGGCCCAATGAGTCCTCTGTTGGGGG 2935

Figure 1. Sequence of the mouse $c d c 25 M 2$ cDNA. The mouse $c d c 25 M 2$ cDNA was identified in a $\lambda Z A P I I$ cDNA library by lowstringency hybridization with a Drosophila stg probe. The cDNA was excised by superinfection with R408 helper phage and doublestranded DNA prepared for sequencing. A 2.9-kb cDNA was sequenced, as discussed in Materials and methods, and the predicted open reading frame is shown. The upstream stop codon is indicated in boldface type, as is methionine 200, the potential alternative start site for translation (see text).

whereas the control transformants were unable to support robust growth on solid medium (Fig. 4a). Similarly, the $c d c 25 M 2$ cDNA was capable of rescuing the $c d c 25$ $22 \mathrm{G}_{2}$ arrest when cells were shifted from $25^{\circ} \mathrm{C}$ to $35^{\circ} \mathrm{C}$, whereas the control plasmid did not (Fig. 4b). We found that the degree of rescue was variable among individual cells, but most cells divided at 1-1.5 times wild-type size. These data establish that Cdc25M2 is able to function as a mitotic inducer in fission yeast and suggest that
Cdc25M2 is likely to function in mitotic control in mouse cells.

\section{Cdc25M2 has phosphatase activity that can dephosphorylate $\mathrm{p}-\mathrm{NPP}$}

Because of the structural similarity between Cdc25M2 and PTPases, we determined whether Cdc25M2 had associated phosphatase activity. We used the phosphatase 


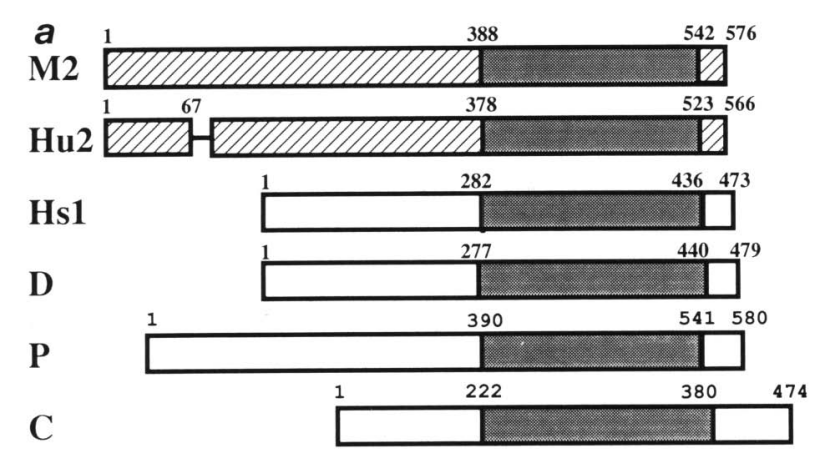

\begin{tabular}{|c|c|c|c|c|c|c|}
\hline & M2 & Hs1 & Hu2 & D & $\mathbf{P}$ & C \\
\hline M2 & & $63 \%$ & $91 \%$ & $52 \%$ & $41 \%$ & $30 \%$ \\
\hline Hs1 & $63 \%$ & & $65 \%$ & $54 \%$ & $39 \%$ & $29 \%$ \\
\hline $\mathrm{Hu} 2$ & $91 \%$ & $65 \%$ & & $52 \%$ & $42 \%$ & $30 \%$ \\
\hline D & $52 \%$ & $54 \%$ & $52 \%$ & & $43 \%$ & $25 \%$ \\
\hline $\mathbf{P}$ & $41 \%$ & $39 \%$ & $42 \%$ & $43 \%$ & & $36 \%$ \\
\hline C & $30 \%$ & $29 \%$ & $30 \%$ & $25 \%$ & $36 \%$ & \\
\hline
\end{tabular}

Figure 2. Comparison of the structure and similarities between cdc25 proteins from various species. $|a|$ Conceptual alignment of $\operatorname{cdc} 25$ proteins from various species. Open boxes indicate regions with little amino acid similarity, hatched boxes indicate homology outside of the conserved carboxyl terminus, and shaded boxes indicate the $\sim 155$-amino-acid region of high identity between all cde 25 proteins. (b) A comparison of the level of amino acid identity among various cde2 5 proteins through the shared region of homology (shaded box in $a$ ). The species shown are mouse (M2), human (Hsl and Hu2), Drosophila (D), S. pombe (P), and S. cerevisiae (C).

assay described by Guan et al. (1990, 1991), which measures the colorimetric conversion of $p$-NPP to $p$-nitrophenol ( $p$-NP). This assay has been used previously to measure the phosphatase activity associated with PTPases like PTP1 from S. cerevisiae, rat brain PTPase, and vaccinia virus PTPase (Guan and Dixon 1991). Residues 278-576 of Cdc25M2 were expressed in $E$. coli as a glutathione $S$-transferase (GST) fusion protein, purified from $E$. coli extracts with glutathione-coupled Sepharose (see Materials and methods), and used to measure $p$-NPP conversion to $p$-NP. Purified, bacterially expressed GSTCdc25M2 dephosphorylated $p$-NPP in a concentrationdependent manner (Fig. 5). Identically expressed and purified GST did not exhibit any phosphatase activity under the same reaction conditions. This confirms the structural observation that Cdc25M2 is related to protein tyrosine phosphatases and suggests that Cdc25M2 is similar functionally to other members of the cdc25 family.

cdc25M2 expression is regulated temporally and developmentally

To examine further the possibility that Cdc25M2 functions as a mitotic inducer in mouse cells, we determined whether cdc25M2 mRNA is expressed periodically in the mouse cell cycle by examining cdc25M2 mRNA lev- els after serum addition to quiescent cells. Swiss $3 T 3$ cells were serum starved for $72 \mathrm{hr}$ to enrich for $\mathrm{G}_{0}$ cells and were then released into fresh medium containing $10 \%$ fetal bovine serum (FBS) (Stein and Stein 1989). Cell cycle progression was followed for $42 \mathrm{hr}$ by measuring the incorporation of radioactive DNA precursors /see Materials and methods). We observed a synchronous round of DNA synthesis as seen by a peak of $\left[{ }^{3} \mathrm{H}\right]$ thymidine incorporation (Fig. 6a). RNA was prepared from these cells, and cdc25M2 levels were measured by Northern blot analysis (Fig. 6b). We observed that $c d c 25 M 2$ mRNA levels were low in $\mathrm{G}_{0}$ phase of the cell cycle, remained low through $\mathrm{G}_{1}$ (which occurs 9-15 hr after addition of serum in these experiments), increased during S phase /which occurs 15-30 hr after serum addition), and reached a plateau $\sim 21-24 \mathrm{hr}$ after the start of this experiment. The peak cdc25M2 mRNA levels reached maximum midway through $S$ phase and remained elevated through the completion of $S$ phase and into $G_{2}-M$. Densitometric scanning indicated that the level of $c d c 25 M 2$ increased about three- to fivefold from $\mathrm{G}_{1}$ to $\mathrm{G}_{2}$ levels. Similar to $C D C 25 \mathrm{Hs} 1$ in HeLa cells, these data establish that the level of mouse cdc25M2 mRNA increases as cells progress through the cell cycle from $G_{1}$ and approach mitosis. We also found that cdc25M2 mRNA levels were readily detectable in logarithmic cells (Fig. 6b), and we note that $c d c 25 M 2$ mRNA levels do not drop dramatically as cells progress through the cell cycle.

To characterize further the expression of cdc25M2 mRNA, we examined its levels in various tissues from an adult rat (Fig. $7 \mathrm{a}$ ) and at different stages during mouse development by Northern analysis (Fig. 7b). We found that $c d c 25 M 2$ mRNA was detectable in most adult tissues. The level of $c d c 25 M 2$ mRNA was lowest in adrenal, kidney, liver, and muscle, was moderately expressed in brain, heart, and intestine and was expressed highest in lung and spleen. We examined the amount of cdc25M2 expression during embryonic development by Northern blotting of mRNA samples from day-10.5 to day-18.5 embryos. We found that total $c d c 25 M 2$ mRNA levels fluctuate during embryonic development and that cdc25M2 mRNA peaks between day 12.5 and 13.5 and remains elevated until day 15.5. After this period, cdc25M2 mRNA levels gradually diminish. We are unable to determine by this analysis whether variation in $c d c 25 M 2$ mRNA level is the result of altered transcription rates, mRNA stability, or merely variation among tissue types.

Because of the variation in mRNA levels in adult tissues and during embryonic development, we determined the spatial distribution of $c d c 25 M 2$ mRNA in embryonic tissues by in situ hybridization. We observed a high and widespread distribution of $c d c 25 M 2$ transcripts in differentiating tissues containing dividing cells/days 10.516.5). In particular, the liver shows high expression in a day-13.5 embryo (Fig. 8a,b), but at day 16.5, the signal has decreased to near-background level (Fig. $8 \mathrm{c}$ ). We also found high levels of $c d c 25 \mathrm{M} 2$ throughout the central nervous system in the early embryo. As cells differenti- 
Figure 3. Sequence alignment of the amino-terminal regions of mammalian cdc 25 proteins. An alignment of the amino acid residues $1-387$ of $\mathrm{Cdc} 25 \mathrm{M} 2$ with $\mathrm{CDC} 25 \mathrm{Hsl}$ and $\mathrm{CDC} 25 \mathrm{Hu} 2$. Amino acid identity is indicated by boxed letters. The alignment was performed with the UWGCG program (Devereaux et al. 1984).

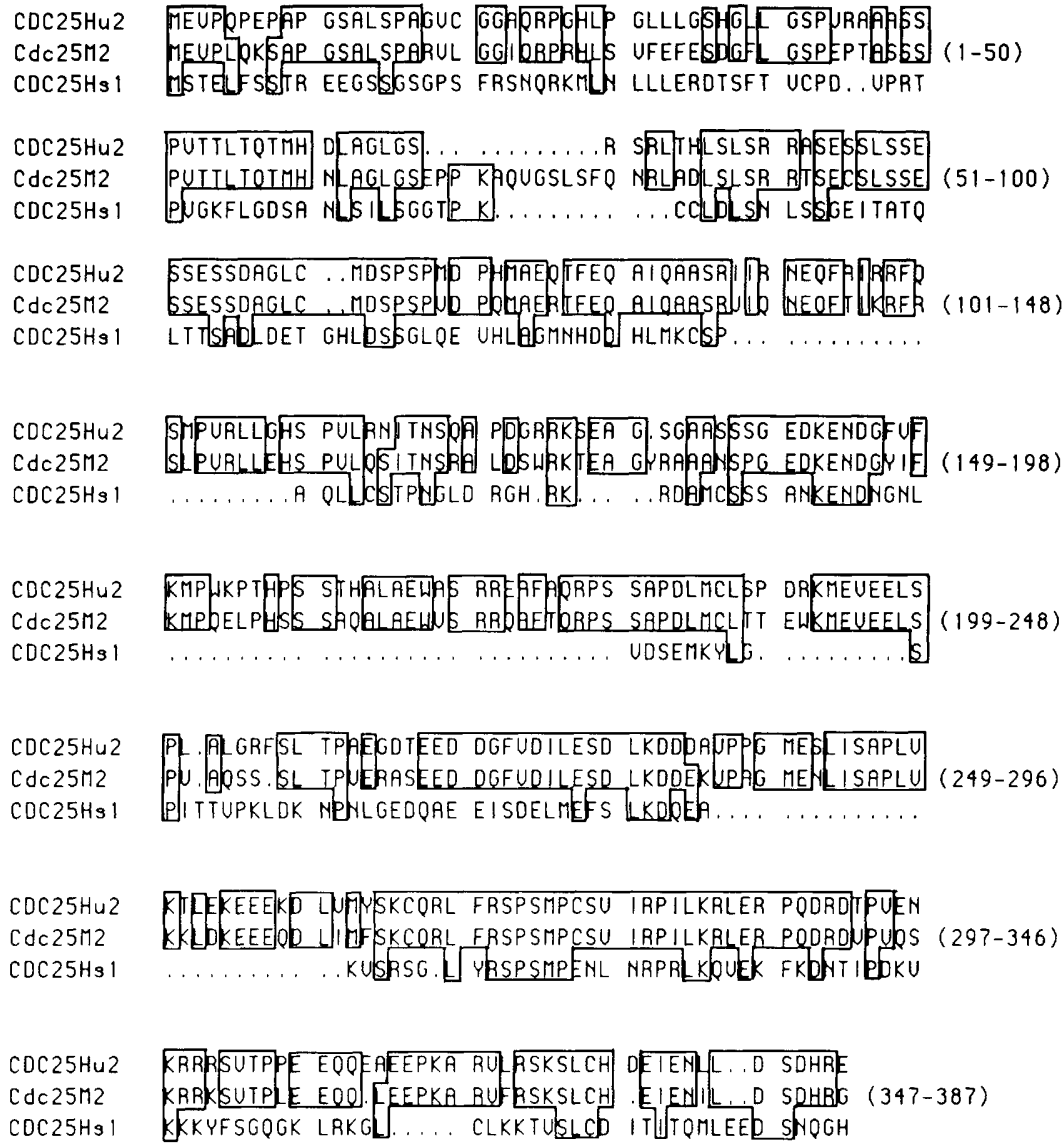

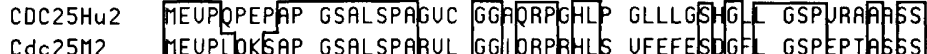
CDC25H3 1 ISTELFSSTR EEGSSGSGPS FRSNQRKMLH LLLERDTSFT UCPD. UPRT

$25 \mathrm{Hu}$

$\mathrm{Cdc} 25 \mathrm{M} 2$

UITLTOTMH NLAGLGSEP P KRQUGSLSFQ NRLADLSLSR RTSECSLSSE $(51-100)$

CCLLL SN LSSGEITATO

$\mathrm{CDC} 25 \mathrm{Hu} 2$
$\mathrm{Cdc} 25 \mathrm{M} 2$

CDC25Hs

SSESSDAGLC, MDSPSPUD PQLAER IFEO ALOARSBULO NEOFTUKRFG (101-148)

TTSSR DET GHLDSSGLOE UHLGMNHDW HLMKCSP.

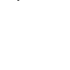

\section{,}

$$
\mathrm{Cde} 25 \mathrm{M2}
$$

CDC25Hu2

$$
\text { Cdc25M2 }
$$

CDC25Hu2

Cdc $25 M 2$

$$
\text { CDC } 25 \mathrm{Hs} 1
$$

CDC25Hu2

Cdc $25 M 2$

$\mathrm{CDC} 25 \mathrm{H}_{3} 1$

$\mathrm{CDC} 25 \mathrm{Hu}$

$\mathrm{COC} 25 \mathrm{Hs}$
KRRKSUTPLE EOO. [EEPKA RUFESKSLCH. EIENIL, D SDHBG (347-387) ate, this expression becomes restricted to regions containing rapidly proliferating cells. For example, as cells in the telencephalon (endbrain) become postmitotic, they migrate toward the periphery and eventually differentiate into the basal ganglia and cerebral cortex. We observed that $c d c 25 \mathrm{M} 2$ expression is concentrated to the ventricular surface of the telencephalon and that there is only weak labeling in the periphery (Fig. 9). There also appears to be a correlation between the order in which the brain vesicles divide and cdc25M2 expression. Cells in the mesencephalon (midbrain) divide after those in the metencephalon (afterbrain) (Kandel and Schwartz 1985). The metencephalon shows high expression of cdc25M2 mRNA in a day-10.5 embryo (not shown) but is reduced to near-background level in a day-13.5 embryo, whereas at this point the mesencephalon (midbrain) shows a strong, highly localized signal (Fig. 8).

Extracellular signals, including growth factors and morphogens, are widely used for controlling mammalian cell proliferation and development. Although the specific intracellular targets for these signals are still obscure, they must change the expression patterns of genes involved in growth control and differentiation. To understand the alteration in expression of $c d c 25 \mathrm{M} 2$ during mouse development, we determined whether $c d c 25 \mathrm{M} 2$ mRNA levels are responsive to a growth factor (serum) that induced immediately early gene expression (Treis- man 1985) and to a morphogen (retinoic acid) that induces proliferation during development (Roberts and Sporn 1984). We starved Swiss 3T3 cells of serum for 72 hr, added $10 \%$ serum, and examined cdc25M2 levels immediately after the induction. In contrast to the wellcharacterized immediate-early response to serum seen with genes like fos (Kruijer et al. 1984), we found that $c d c 25 \mathrm{M} 2$ transcription was not induced rapidly by serum (Fig. 6).

To determine whether $c d c 25 M 2$ levels are responsive to retinoic acid, we examined the induction of $c d c 25 \mathrm{M} 2$ after an 8-hr treatment of embryonal carcinoma P19 cells with varying concentrations of retinoic acid. As shown in Figure 10, we found that cdc25M2 mRNA was induced 5- to 10 -fold by retinoic acid treatment. The time course of retinoic acid induction of $c d c 25 \mathrm{M} 2 \mathrm{mRNA}$ is similar to the retinoic acid induction seen for retinoic acid receptor $\beta$ mRNA (RAR $\beta$ ) (Song and Siu 1989). To test whether retinoic acid induction was a primary event, we determined whether induction occurred in the presence of cycloheximide. However, similar to many highly unstable mRNAs (Graves et al. 1987; Müllner and Kühn 1988; Shyu et al. 1989), we found that the addition of cycloheximide resulted in higher steady-state cdc25M2 mRNA levels after induction with retinoic acid. This precludes determination of whether retinoic acid induction is a primary event. 
$\mathbf{a}$

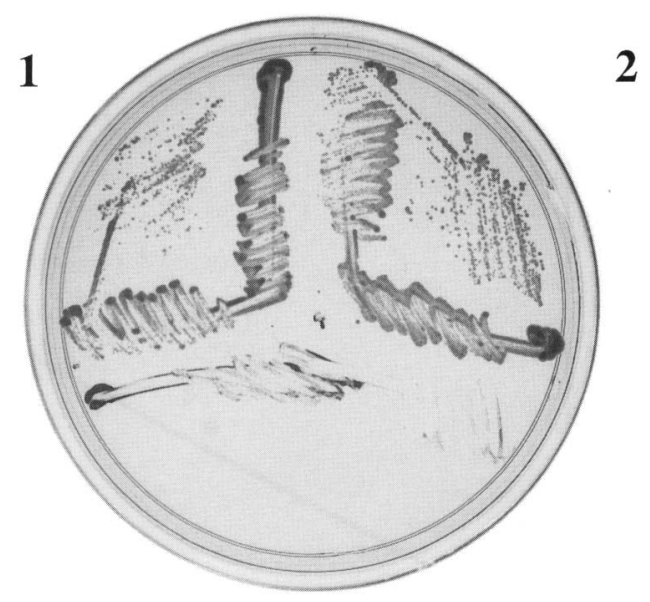

3

b

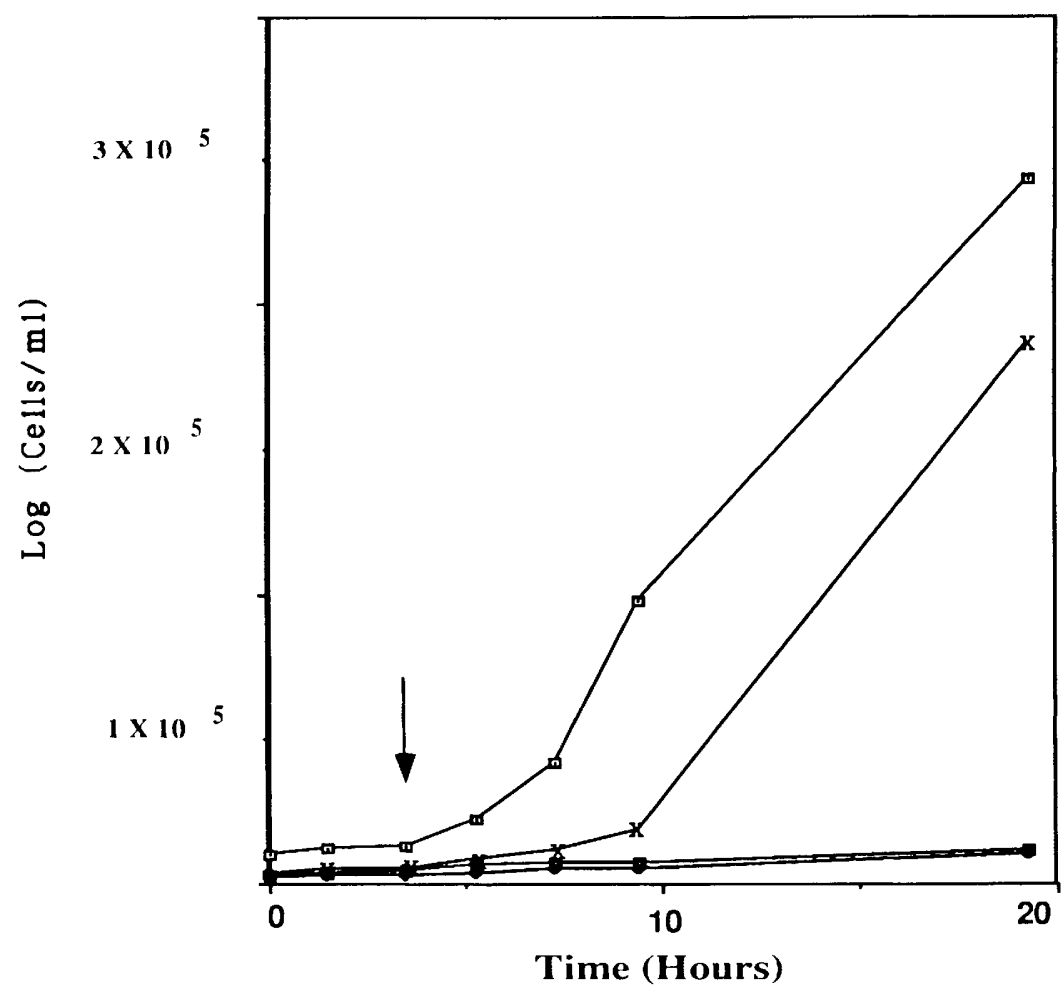

Figure 4. The mouse $c d c 25 M 2$ gene is a functional homolog of $S$. pombe cdc25. (a) $S$. pombe strains were transformed to $\mathrm{Leu}^{+}$ and grown at room temperature. Both wildtype $c d c 25^{+}$and $c d c 25^{t s}$ strains were transformed. Transformants were single-colonypurified on EMM medium, streaked for single colonies on YES medium, and incubated at the $c d c 25^{t s}$ nonpermissive temperature of $35^{\circ} \mathrm{C}$. Sector 1 shows a vector-control Leu ${ }^{+}$cdc25 $5^{+}$transformant; sector 2 contains a $c d c 25^{t s}$ strain transformed to $\mathrm{Leu}^{+}$with a cdc25M2-containing plasmid; sector 3 shows a Leu ${ }^{+}$vectoralone $c d c 25^{t s}$ strain. (b) Various $S$. pombe strains were grown overnight in EMM liquid medium to mid-log phase. Cultures were transferred by dilution into YES media, grown for several hours at permissive temperature, and shifted to nonpermissive temperature $\left(35^{\circ} \mathrm{C}\right)$. Growth was monitored as described (Russell and Nurse 1987). Arrow indicates the time point when cultures were shifted to nonpermissive temperature $\left(35^{\circ} \mathrm{C}\right) .(\times)$ cdc25-22 + cdc25M2; (口) cdc25$22+$ vector; $(\square) c d c 25^{+} ;(\diamond) c d c 25-22$.

\section{Discussion}

To understand how extracellular signal molecules such as growth factors and morphogens act in mammalian cell proliferation and development, we have isolated a mouse homolog of the Drosophila stg gene. The D. melanogaster stg gene product is a regulator of embryonic cell cycles (Edgar and O'Farrell 1990). The stg gene product is functionally identical to the fission yeast rate-limiting mitotic inducer cdc25 and is one possible candidate for a developmental target for growth control and differentiation.

cdc25M2 is a functional homolog of the $S$. pombe cdc25 gene. The mouse gene is fully capable of restoring the temperature-conditional growth defect associated with the $c d c 25-22$ temperature-sensitive mutation and allows cdc25M2 transgenic fission yeast to grow at nearly wild-type rates in broth medium, to form normal colonies on agar medium at the nonpermissive temperature, and to divide at nearly normal cell size (Fig. 4). Complementation occurs despite the fact that $c d c 25 M 2$ expression is not cell cycle regulated in $S$. pombe, as the protein is overexpressed from the SV40 promoter.

Cdc25M2 shows striking amino acid identity throughout its amino-terminal noncatalytic region to $\mathrm{CDC} 25 \mathrm{Hu} 2$, whereas neither of these predicted gene 
Figure 5. Mouse Cdc25M2 can dephosphorylate $p$-NPP. The indicated amounts of purified recombinant GST-Cdc25M2 protein (घ) or GST protein $(\bullet)$ were incubated with $p$-NPP as described in Materials and methods. The reactions were incubated for $45 \mathrm{~min}$ at $30^{\circ} \mathrm{C}$, terminated with the addition of 0.2 $\mathrm{M} \mathrm{NaOH}$, and $p$-NP production was measured by absorbance at $410 \mathrm{~nm}$. Under these conditions, the dephosphorylation of $p$-NPP is linear with respect to protein concentration and with time (not shown).

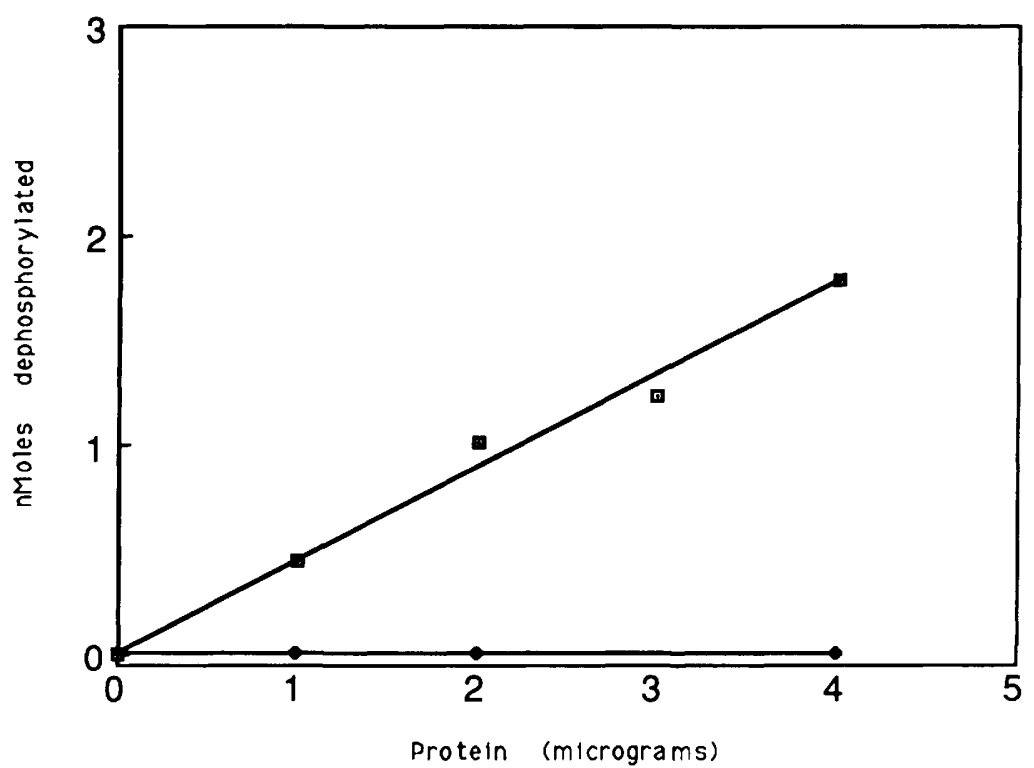

Sebastian, A. Kakizuka, R.M. Evans, and T. Hunter, unpubl.).

The importance of $c d c 25$ homologs in regulating the onset of mitosis has been established in a number of systems. The $c d c 25$ homologs identified in S. pombe and D. melanogaster are essential (Russell and Nurse 1987;
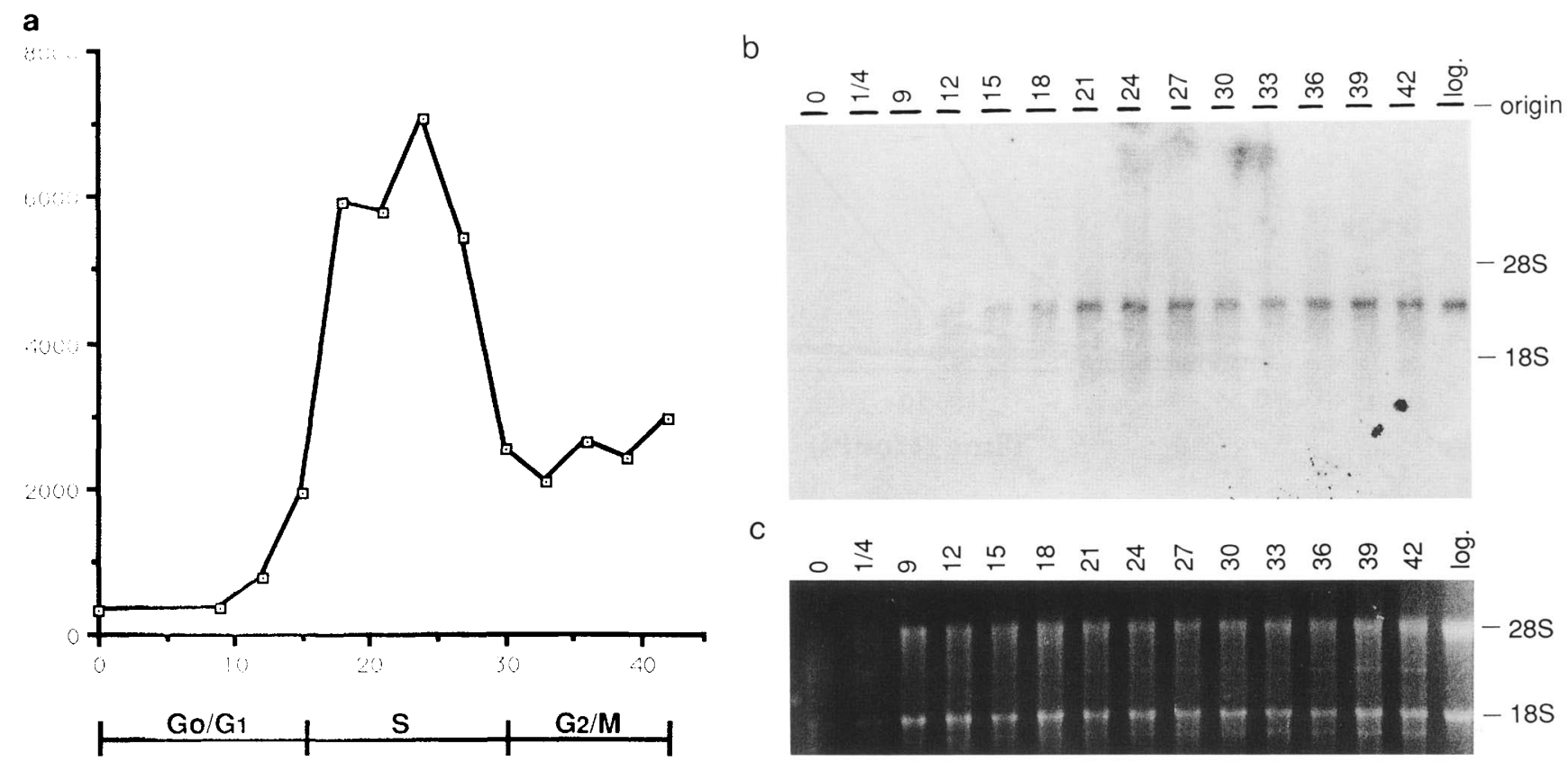

Figure 6. Expression of $c d c 25 M 2$ is regulated during the mouse cell cycle. $(a)$ The incorporation of $\left[{ }^{3} \mathrm{H}\right]$ thymidine into DNA was monitored at various times after addition of $10 \%$ serum; the average of two measurements is shown. The $y$-axis corresponds to cpm measured; the $x$-axis corresponds to hours after serum addition. Periods in the cell cycle are shown below the diagram. $(b)$ Total RNA was isolated at various times after addition of serum to quiescent Swiss 3T3 cells. Five micrograms of total RNA for each time point was analyzed by Northern blotting. Numbers indicate hours after serum addition. Log indicates cells in log phase grown continuously in the presence of serum. The filter was probed with $c d c 25 M 2$ cDNA. (c) Ethidium bromide staining of $18 \mathrm{~S}$ and $28 \mathrm{~S}$ rRNA for the RNAs analyzed above. Samples from the 0 - and 15 -min time points showed weak rRNA staining. 


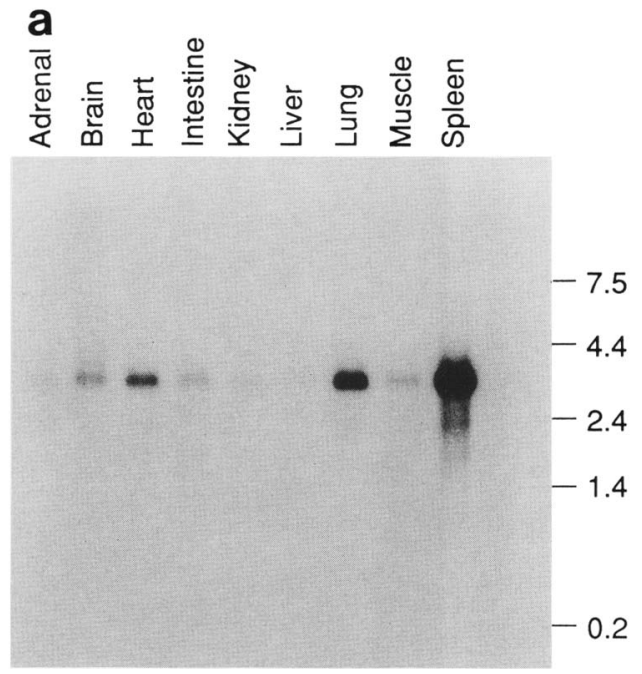

Figure 7. CDC25M2 expression varies during embryonic development and between tissues. (a) Five micrograms of poly $(\mathrm{A})^{+}$RNA from various adult rat tissues was analyzed by Northern blotting. The probe was CDC25M2 cDNA. $|b|$ Ten micrograms of poly $(A)^{+}$RNA from various stage mouse embryos was examined by Northern blotting.

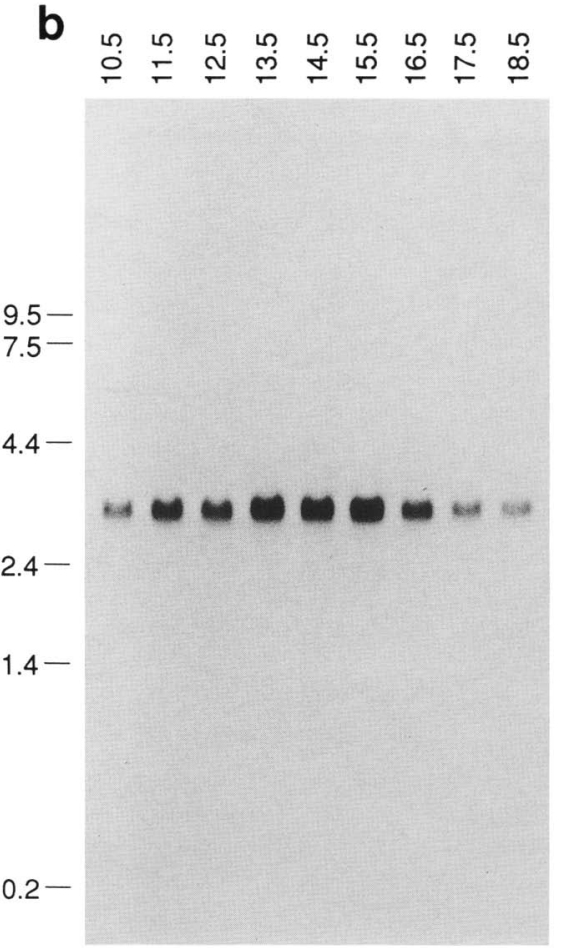

phosphorylate and activate starfish $\mathrm{p} 34^{\mathrm{cdc} 2} /$ cyclin B complex in vitro (Strausfeld et al. 1991). Structural comparisons of $c d c 25^{+}$from $S$. pombe to known PTPases identified an "HCXXXXXR" motif that is found in the vaccinia virus $\mathrm{VH}$ l phosphatase and is conserved among all cdc25 homologs (Guan et al. 1991; Moreno and Nurse 1991). The cysteine in this motif is essential to VHl phosphatase activity (Guan et al. 1991). When this cysteine is mutated, bacterially expressed cdc 25 loses its phosphatase activity and its ability to activate $\mathrm{p} 34^{\mathrm{cdc} 2} /$ cyclin B (Dunphy and Kumagai 1991; Gautier et al. 19911.

We believe that Cdc25M2 also acts as a protein phosphatase. A purified bacterially expressed GST-Cdc25M2 fusion protein dephosphorylates $p$-NPP (Fig. 5). Given the evidence discussed above, a possible in vivo substrate for Cdc25M2 is $\mathrm{p} 34^{\mathrm{cdc}} / \mathrm{cyclin} \mathrm{B}$. Vertebrate $\mathrm{p} 34^{\mathrm{cdc} 2} /$ cyclin B activity is inhibited by phosphorylation on T-14 as well as Y-15 (Krek and Nigg 1991; Norbury et al. 1991). This raises the possibility that Cdc25M2 is perhaps a "dual-specificity" phosphatase that dephosphorylates both Y-15 and T-14; alternatively, two different phosphatases may be required-one for each residue.

Whereas expression of $c d c 25$ is rate limiting for mitosis in $S$. pombe and varies throughout the cell cycle (Russell and Nurse 1987; Moreno et al. 1990), a similar relationship has not been established for mammalian cells. CDC25Hsl protein levels appear to be relatively constant throughout the cell cycle (Millar et al. 1991). Despite the variation in CDC25Hs1 mRNA /Sadhu et al. 1990), CDC25Hu2 mRNA varies only slightly (Nagata et al. 1991). Upon stimulating Swiss 3 T3 cells to 
a

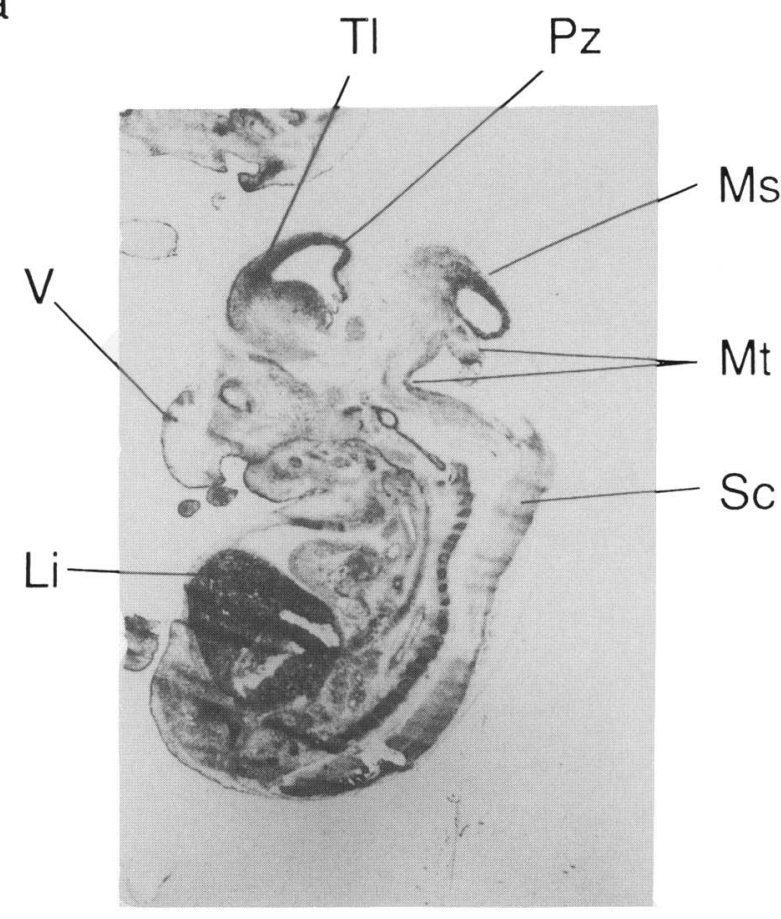

b

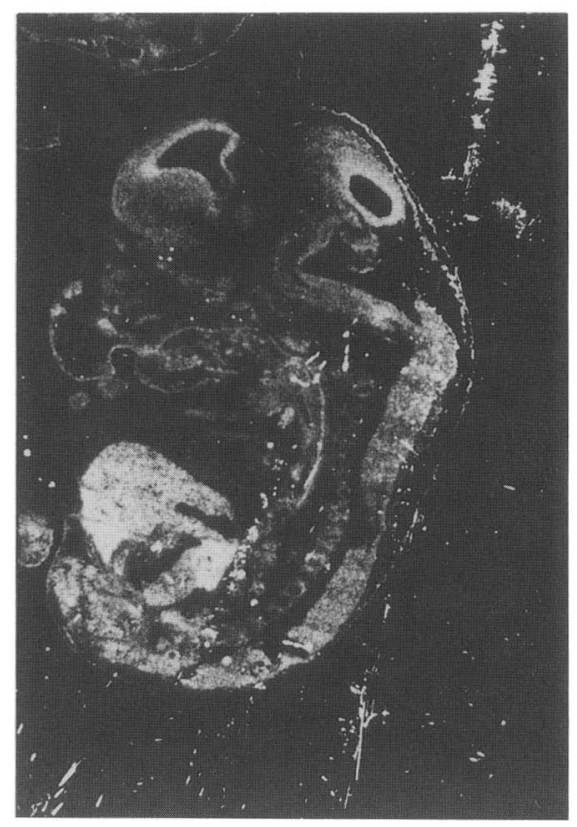

C

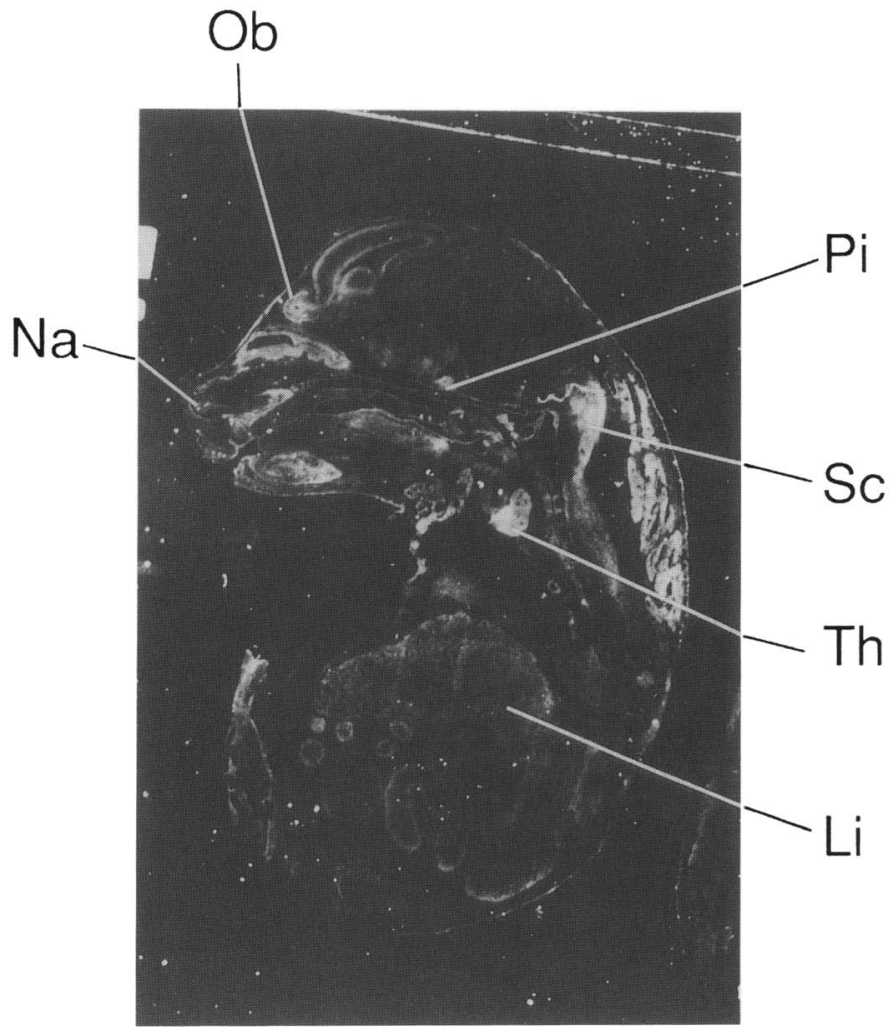

In Drosophila, increasing levels of regulation act upon mitosis as an embryo develops. The first 13 rapid cycles in the fly syncytial embryo rely on maternal gene products (for review, see Glover 1991). These 13 divisions 
a

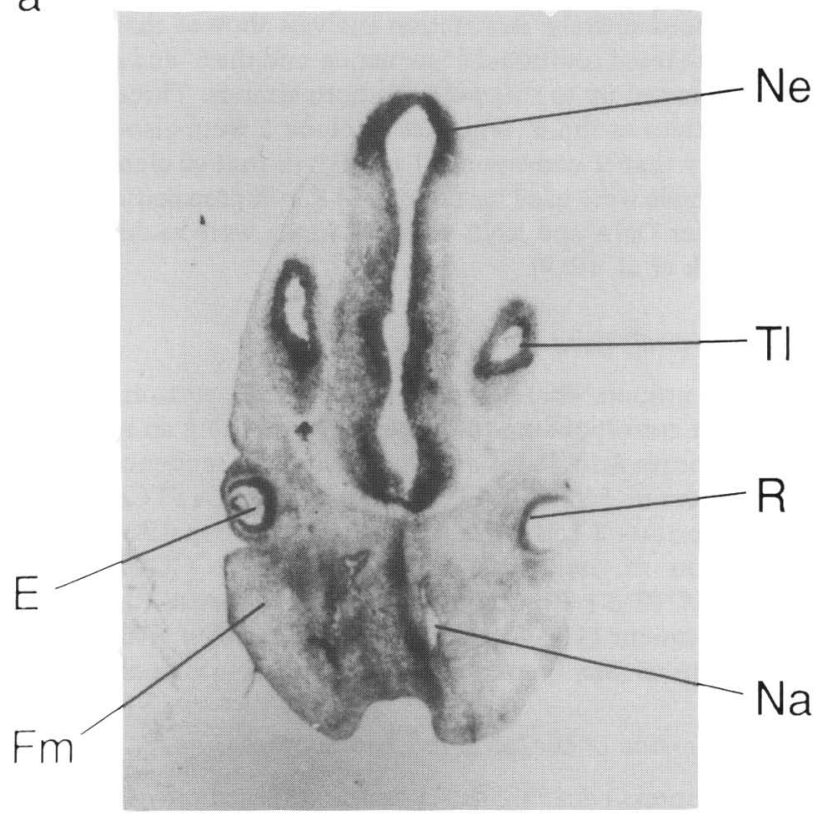

b

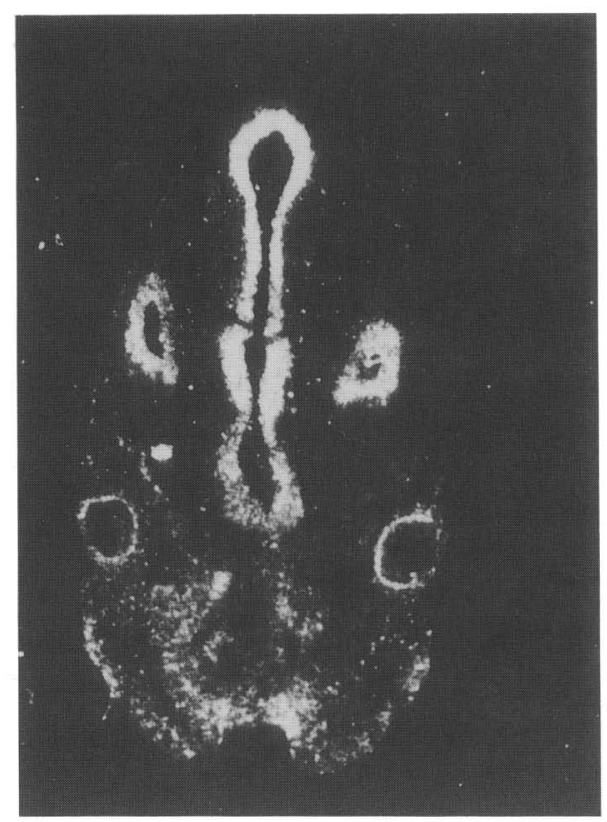

Figure 9. $c d c 25 M 2$ expression in the central nervous system of a mouse embryo. (a) A coronal section of the head of an E12.5 mouse embryo. (Ne) Neuroepithelium; (Tl) telencephalon; $(\mathrm{R})$ retina; $(\mathrm{Na})$ nasal cavity; $(\mathrm{Fm})$ facial mesenchyme; $(E)$ eye. $(b)$ Dark-field autoradiograph showing expression of $c d c 25 M 2$ in the embryonic section in $a$.

lack the cdc25-dependent feedback regulation that monitors completion of $\mathrm{S}$ phase. Such regulation is introduced in cycle 14 with the beginning of an apparent $\mathrm{G}_{2}$ phase and a coordinated network of mitotic control that is under the overall control of stg. After the onset of cellularization in the fourteenth division cycle, fly somatic cells undergo mitotic divisions that are coordinated with the process of gastrulation and morphogenesis. In wild-type embryos, short-lived zygotic stg transcripts precede and induce the spatiotemporal onset of mitosis.

We anticipated that the universal mitotic control defined by developmental studies in D. melanogaster may hold true in mouse development. To test the notion that high levels of $c d c 25 \mathrm{M} 2$ might correlate with proliferating cells, we analyzed the levels of $c d c 25 \mathrm{M} 2 \mathrm{mRNA}$ in the developing mouse. The $c d c 25 M 2$ gene shows a temporal and spatial pattern of expression during embryonic development. $c d c 25 \mathrm{M} 2 \mathrm{mRNA}$ is most abundant during days 13.5-16.5 in development; after day 15.5, this level declines rapidly. In situ hybridizations of $c d c 25 M 2$ antisense RNA show that the $c d c 25 M 2$ gene is widely expressed in differentiating tissues containing dividing cells. In particular, there appears to be a correlation between $c d c 25 M 2$ expression and the presumed region and timing of mitosis in cells in the liver and the central nervous system. cdc25M2 expression in the liver is found in day-13.5 embryos, during which rapid cell division occurs, and has decreased in the liver in a day-16.5 embryo, at which point proliferation in liver cells has presumably dropped sharply (Fig. 8). A high level of cdc25M2 transcript was detected in regions in the nervous system containing rapidly dividing cells such as the neuroepithelium (Fig. 9) and proliferative zone (Fig. 8b), whereas strong signals were not observed in the periphery of the neural tube, which contains postmitotic, differentiated cells (Fuiita 1964). Finally, the timing of cdc25M2 expression in the brain vesicles such as the telencephalon, mesencephalon, and metencephalon is consistent with the order in which the cells in these regions divide. The differential localization of $c d c 25 \mathrm{M} 2$ in the mouse embryo suggests that elucidation of the developmental role of each type of cdc25 protein within an organism might be informative.

Mammalian cell proliferation and development are responsive to diverse extracellular signals. We found that cdc25M2 mRNA levels were clearly inducible by retinoic acid treatment in P19 cells and that cdc25M2 mRNA could be stabilized by cycloheximide treatment. This suggests that cdc25M2 mRNA is unstable and might be prone to regulation by cotranslational processing in a fashion similar to the regulation of early response genes like fos and myc or by cell cycle-controlled instability as seen for histone mRNA or for tubulin. In addition, retinoic acid induction of $c d c 25 M 2$ expression suggests that $c d c 25 M 2$ gene is one potential intracellular target for growth control and differentiation. The precise mechanism of $c d c 25 \mathrm{M} 2$ induction will require the isolation of its promoter element. Furthermore, it is unclear whether the degradation of $c d c 25 M 2$ mRNA is translation dependent like tubulin mRNA (Pachter et al. 1987; Gay et al. 1989) or cell cycle controlled like histone mRNA (Gallwitz 1975; DeLisle et al. 1983; Heintz et al. 1983). However, these results indicate that a universal mitotic control element can act either as a direct or indirect target for extracellular developmental signals. 
a

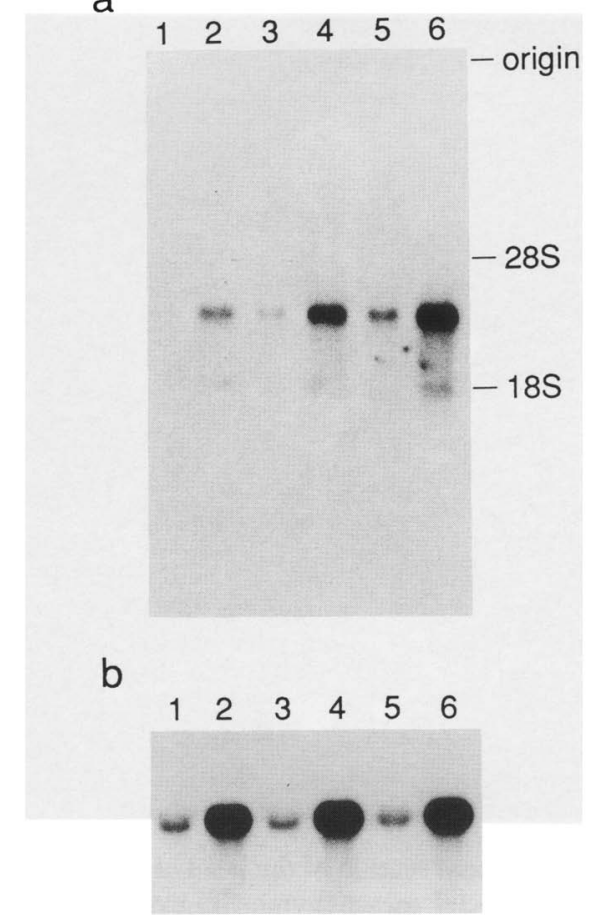

Figure 10. CDC25M2 expression is induced by retinoic acid in mouse P19 embryonic teratocarcinoma cells. (a) RNA samples were prepared from P19 cells treated with $10 \mu \mathrm{g} / \mathrm{ml}$ of cycloheximide without retinoic acid (lanes 1,2) and with $10^{9} \mathrm{M}$ (lanes 3,4$)$ or $5 \times 10^{7} \mathrm{M}$ (lanes 5,6$)$ of retinoic acid for $8 \mathrm{hr}$. Paired samples of $15 \mu \mathrm{g}$ of total RNA (lanes $1,3,5$ ) and $5 \mu \mathrm{g}$ of poly $(\mathrm{A})^{+}$RNA (lanes $\left.2,4,6\right)$ from each treatment were analyzed by Northern blotting using CDC $25 \mathrm{M} 2$ cDNA as a probe. $\langle b|$ The filter above was rehybridized with a cDNA whose expression level was not affected by the presence of retinoic acid. RNA samples and retinoic acid treatment correspond to the lanes described in $a$.

\section{Materials and methods}

\section{Isolation of cdc25M 2 cDNA}

Poly $(\mathrm{A})^{+}$RNA from mouse P19 teratocarcinoma cells was used as a source material for cDNA library construction. Isolation of total RNA and purification of poly $(\mathrm{A})^{+}$RNA were carried out as described (Chomczynski and Sacchi 1987; Kakizuka et al. 1988). First-strand synthesis was primed with oligo(dT), and the double-stranded cDNA was prepared as described previously (Kakizuka et al. 1991). The library was constructed in $\lambda$ ZAPII (Stratagene). A portion of the Drosophila stg gene encoding the conserved catalytic domain of the $c d c 25$ homologs was isolated as a PCR fragment and used as a probe in low-stringency hybridization (Edgar and O'Farrell 1990) to screen for mouse homologs. The hybridization of the membrane filters (Colony/ Plaque Screen, Dupont) was carried out in $1 \mathrm{M} \mathrm{NaCl}, 50 \mathrm{mM}$ Tris- $\mathrm{HCl}(\mathrm{pH} 7.5), 1 \%$ SDS, $10 \%$ dextran sulfate, $100 \mu \mathrm{g} / \mathrm{ml}$ of denatured salmon sperm DNA, $200 \mu \mathrm{g} / \mathrm{ml}$ of yeast RNA, and 5 $\mathrm{ng} / \mathrm{ml}$ of ${ }^{32} \mathrm{P}$-labeled probe $\left(\sim 5 \times 10^{8} \mathrm{cpm} / \mu \mathrm{g}\right)$ at $60^{\circ} \mathrm{C}$. The filters were washed in $2 \times \mathrm{SSC}$ and $0.1 \%$ SDS at $55^{\circ} \mathrm{C}$. From 25,000 recombinant phages, 10 positives were identified and one of them showed amino acid similarity to that of $s t g$. Recombinant phages $(300,000)$ were rescreened using the cDNA as a probe, and 20 positives were identified. The cDNA inserts in these phages were excised and restriction mapped. Clone 4 was sequenced entirely. Restriction analysis showed that clones 2 and 6 contained additional $5^{\prime}$ sequence, and the $5^{\prime}$ end of clone 6 was sequenced up to this point on both strands. Three hundred nucleotides of the $3^{\prime}$ sequence of clone 2 were also sequenced to verify that it corresponded exactly to that of clone 4 . Standard methods were used for phage and E. coli propagation, and methods for DNA and RNA manipulations were as described (Sambrook et al. 1989).

\section{PCR analysis of cdc25M2 $m R N A$}

PCR primers were designed to amplify the portion of CDC25M2 RNA corresponding to the region containing an insert in clone 4. Primer A included an Sau3AI site and sequence upstream of nucleotide 560 (5'-GATCTGAACAGGCCATTCAGGCAG-3'), and primer $B$ contained sequence on the opposite strand downstream of nucleotide 560 (5'-GATCCTCGGTAGCCTGCTTCAGTT-3'). Reverse transcription of mouse P19 mRNA and subsequent PCR was performed as described with minor modifications (Sambrook et al. 1989; Middlemas et al. 1991).

\section{Expression of cdc25M2 in S. pombe}

To express $c d c 25 M 2$ in $S$. pombe, we fused the $c d c 25 M 2$ cDNA to the SV40 early promoter (Lee and Nurse 1987). The cdc25M2 cDNA was cloned as a SalI-BamHI fragment into a LEU2, $2 \mu$ origin-based plasmid. The SV40 early promotor from plasmid $\mathrm{pCH} 10$ (Pharmacia-LKB) was cloned adjacent to the $5^{\prime}$ end of cdc25M2. This plasmid and a control vector lacking the cdc25M2 cDNA were transformed into a leu1 cdc25-22 strain (kindly provided by P. Nurse and K. Gould), and Leu ${ }^{+}$transformants were selected at $24^{\circ} \mathrm{C}$ on EMM media (Moreno et al. 1991). S. pombe transformation followed standard procedures. Transformants were grown at room temperature to mid-log phase in EMM media, and the cultures were split into YES media (Moreno et al. 1991) and shifted to the $c d c 25^{\text {ts }}$ nonpermissive temperature $\left(35^{\circ} \mathrm{C}\right)$. Growth of the culture was followed by microscopic examination of Calcofluor-stained cells (Russell and Nurse 1987) and by cell number determination with a Coulter counter as described (Russell and Nurse 1987; Sadhu et al. 1990).

\section{Expression and purification of a GST-CDC25M2 fusion} protein and detection of phosphatase activity

A 1-kb DraI-Ncol fragment was isolated from the cloned cDNA of $c d c 25 M 2$ (Fig. 1) and ligated into SmaI-Ncol-digested pGEXKG /Guan and Dixon 1991) to produce pGEX-K288. E. coli strain BL21 containing plasmid pLysS was transformed with pGEX$\mathrm{K} 288$, and cells containing both plasmids were grown in $800 \mathrm{ml}$ of $\mathrm{L}$ broth at $37^{\circ} \mathrm{C}$ to mid-log phase and treated with $0.6 \mathrm{~mm}$ IPTG for $2 \mathrm{hr}$ at $25^{\circ} \mathrm{C}$. Cells were harvested, washed in TD (150 $\mathrm{mm} \mathrm{NaCl}, 10 \mathrm{~mm}$ Tris- $\mathrm{HCl}$ at $\mathrm{pH} 7.5$ ), resuspended in TD containing both $1 \%$ Tween 20 and $1 \%$ Triton X-100, and the mixture was sonicated for $30 \mathrm{sec}$. The extract was centrifuged twice at $2500 \mathrm{rpm}$ for $10 \mathrm{~min}$ in a Beckman J6B centrifuge, and the clarified supernatant was collected. Five hundred microliters $[50 \%(\mathrm{vol} / \mathrm{vol})]$ of Sepharose (Pharmacia), coupled with glutathione, was added to the extract, and the slurry was incubated for $2-3 \mathrm{hr}$ at $4^{\circ} \mathrm{C}$. The beads were collected by centifugation for 10 $\mathrm{sec}$ at $1000 \mathrm{rpm}$ and washed extensively in $500 \mathrm{mM} \mathrm{NaCl}, 10$ $\mathrm{mM}$ DTT, and $10 \mathrm{~mm}$ HEPES ( $\mathrm{pH}$ 8.0). Protein was eluted by incubating the beads for $3-4 \mathrm{hr}$ at $4^{\circ} \mathrm{C}$ in $100 \mathrm{~mm}$ Tris- $\mathrm{HCl} / \mathrm{pH}$ $8.0), 10 \mathrm{~mm}$ DTT, and $5 \mathrm{~mm}$ glutathione. GST from pGEX-KG was purified in an identical manner. Protein concentration was determined by gel electrophoresis. 
To assay the activity of the purified GST-Cdc25M2 fusion protein, we measured dephosphorylation of $p$-NPP using the conditions described by Guan et al. (1990, 1991). Reaction mixtures $(200 \mu l)$ contained $50 \mathrm{~mm}$ imidazole $(\mathrm{pH} 7.4), 0.5 \% \beta$-mercaptoethanol, and $10 \mathrm{~mm} p$-NPP, and either purified GSTCdc25M2 fusion protein or GST, and the reactions were incubated at $30^{\circ} \mathrm{C}$ for $45 \mathrm{~min}$. Reactions were terminated by adding $800 \mu \mathrm{l}$ of $0.2 \mathrm{M} \mathrm{NaOH}$. Absorbance at $410 \mathrm{~nm}$ was measured.

\section{Analysis of cdc25M2 mRNA levels}

cdc25M2 mRNA levels were analyzed by Northern blots using a randomly primed $c d c 25 \mathrm{M} 2 \mathrm{cDNA}$ insert as a probe. Total and poly $(\mathrm{A})^{+}$mRNA was isolated as described above. Total or poly $(\mathrm{A})^{+}$RNA was separated by electrophoresis in a $1 \%$ agarose gel containing $0.66 \mathrm{M}$ formaldehyde, transferred to a Nytran filter (Schleicher \& Schuell), and hybridized with cdc25M2 cDNA. Hybridization was carried out at $42^{\circ} \mathrm{C}$ in a buffer containing $50 \%$ formamide, $50 \mathrm{mM}$ sodium phosphate buffer $(\mathrm{pH}$ $6.5), 5 \times$ SSC, $4 \times$ Denhardt's solution, $0.1 \%$ SDS, $100 \mu \mathrm{g} / \mathrm{ml}$ of denatured salmon sperm DNA, $200 \mu \mathrm{g} / \mathrm{ml}$ of yeast RNA, and 5 $\mathrm{ng} / \mathrm{ml}$ of ${ }^{32} \mathrm{P}$-labeled probe $\left(\sim 5 \times 10^{8} \mathrm{cpm} / \mu \mathrm{g}\right)$. The filters were washed with $0.5 \times \mathrm{SSC}$ and $0.1 \%$ SDS at $50^{\circ} \mathrm{C}$ and exposed to film with an intensifying screen. Total RNA from adult male rat tissues and mouse embryos was isolated as described previously (Chomczynski and Sacchi 1987).

To examine cdc25M2 mRNA levels during cell cycle progression, the methods described by Lee et al. (1988) were used. Briefly, Swiss 3T3 cells were maintained in DMEM with $0.5 \%$ FBS for $72 \mathrm{hr}$. At this time we estimate that $>90 \%$ of the cells were in $\mathrm{G}_{0}$. Fresh medium (DMEM) containing $10 \%$ FBS was added to the serum-depleted cells, and samples were taken at various times after addition. Progression through the cell cycle was monitored by labeling cells for $30 \mathrm{~min}$ with $10 \mu \mathrm{Ci}$ of $\left[{ }^{3} \mathrm{H} \mid\right.$ thymidine $(83 \mathrm{Ci} / \mathrm{mmole}$, Amersham) prior to harvesting. Incorporation of $\left[{ }^{3} \mathrm{H}\right]$ thymidine into DNA was measured as described (Stein and Stein 1989) but briefly involved washing the media from cells, lysing the cells, precipitating DNA with cold trichloroacetic acid (TCA), and measuring incorporation of ${ }^{3} \mathrm{H}$ into TCA-precipitated DNA. Parallel samples of cells were harvested for RNA preparation and Northern analysis.

Retinoic acid induction experiments were performed as follows: Monolayer cultures of P19 cells were maintained in $\alpha \mathrm{MEM}$ with $10 \%$ FBS and were treated by $10 \mu \mathrm{g} / \mathrm{ml}$ of cycloheximide (Calbiochem) with or without $10^{-9} \mathrm{M}$ or $5 \times 10^{-7} \mathrm{M}$ retinoic acid (Sigma) for $8 \mathrm{hr}$. The effect of retinoic acid was monitored by Northern blot using the RAR $\beta$ cDNA as a probe (Song and Siu 1989).

\section{In situ hybridization of cdc25M to developing mouse} embryos

In situ hybridization was performed as described by Bettler et al. (1990). Two antisense RNA probes covering nucleotides 7381274 and $1360-1703$ (Fig. 1) were prepared using ${ }^{35} \mathrm{~S}$-labeled UTP (1500 Ci/mmole, Dupont) and T3 RNA polymerase (Promega). Both probes gave identical results. Unrelated probes (Bettler et al. 1990) were used to determine specificity (data not shown). The occurrence of a vaginal plug was defined as EO.

\section{Acknowledgments}

Thanks go to Kathy Gould and Paul Nurse for $S$. pombe strains and cloning vectors, David J. Mangelsdorf for the tissue RNAs, David Chantry for critical reading of the manuscript, and Jack Dixon and K. Guan for the pGEX-KG vector. This work was supported in part by a grant to M.F.H. from the Lucille P. Markey Charitable Trust. M.F.H. is a Lucille F. Markey Scholar in Biomedical Sciences. R.M.E. is an Investigator of the Howard Hughes Medical Institute. These studies were supported in part by the Howard Hughes Medical Institute and the Weingart Foundation.

The publication costs of this article were defrayed in part by payment of page charges. This article must therefore be hereby marked "advertisement" in accordance with 18 USC section 1734 solely to indicate this fact.

\section{Note added in proof}

Galaktionov and Beach (1991, Cell 67: 1181-1194) reported the third member of human $c d c 25$.

\section{References}

Bettler, B., J. Boulter, I. Hermans-Borgmeyer, A. O'Shea-Greenfield, E.S. Deneris, C. Moll, U. Borgmeyer, M. Hollmann, and S. Heinemann. 1990. Cloning of a novel glutamate receptor subunit, GluR5: Expression in the nervous system during development. Neuron 5: 583-595.

Chomczynski, P. and N. Sacchi. 1987. Single-step method of RNA isolation by acid guanidinium thyocyanate-phenolchloroform extraction. Anal. Biochem. 162: 156-159.

Cool, D.E., N.K. Tonks, H. Charbonneau, K.A. Walsh, E.H. Fischer, and E.G. Krebs. 1989. cDNA isolated from a human T-cell library encodes a member of the protein-tyrosinephosphatase family. Proc. Natl. Acad. Sci. 86: 5257-5261.

DeLisle, A.J., R.A. Graves, W.F. Marzluff, and L.F. Johnson. 1983. Regulation of histone mRNA production and stability in serum-stimulated mouse 3T6 fibroblasts. Mol. Cell. Biol. 3: $1920-1929$.

Devereux, J., P. Haeberli, and O. Smithies. 1984. A comprehensive set of sequence analysis programs for the VAX. Nucleic Acids Res. 12: 387-395.

Dunphy, W.G. and A. Kumagai. 1991. The cdc25 protein contains an intrinsic phosphatase activity. Cell 67: 189-196.

Edgar, B.A. and P.H. O'Farrell. 1990. The three postblastoderm cell cycles of Drosophila embryogenesis are regulated in G2 by string. Cell 62: 469-480.

Evans, T., E.T. Rosenthal, J. Youngblom, D. Distel, and T. Hunt. 1983. Cyclin: A protein specified by maternal mRNA in sea urchin eggs that is destroyed at each cleavage division. Cell 33: 389-396.

Feilotter, H., P. Nurse, and P.G. Young. 1991. Genetic and molecular analysis of cdr1/nim1 in Schizosaccharomyces pombe. Genetics 127: 309-318.

Fujita, S. 1964. Analysis of neuron differentiation in the central nervous system by tritiated thymidine autoradiography. $J$. Comp. Neurol. 122: 311-327.

Gallwitz, D. 1975. Kinetics of inactivation of histone mRNA in the cytoplasm after inhibition of DNA replication in synchronised HeLa cells. Nature 257: 247-248.

Gautier, J., M.J. Solomon, R.N. Booher, J.F. Bazan, and M.W. Kirschner. 1991. cdc25 is a specific tyrosine phosphatase that directly activates $\mathrm{p} 34^{\mathrm{cdc} 2}$. Cell 67: 197-211.

Gay, D.A., S.S. Sisodia, and D.W. Cleveland. 1989. Autoregulatory control of $\beta$-tubulin mRNA stability is linked to translation elongation. Proc. Natl. Acad. Sci. 86: 5763-5767.

Glover, D.M. 1991. Mitosis in the Drosophila embryo-In and out of control. Trends Genet. 7: 125-132.

Gould, K.L. and P. Nurse. 1989. Tyrosine phosphorylation of the fission yeast $c d c 2^{+}$protein kinase regulates entry into mitosis. Nature 342: 39-45.

Gould, K.L., S. Moreno, N.K. Tonks, and P. Nurse. 1990. Com- 
plementation of the mitotic activator, $\mathrm{p} 80^{\text {cdc25 }}$, by a human protein-tyrosine phosphatase. Science 250: 1573-1576.

Graves, R.A., N.B. Pandey, N. Chodchoy, and W.F. Marzluff. 1987. Translation is required for regulation of histone mRNA degradation. Cell 48: 615-626.

Guan, K. and J.E. Dixon. 1991. Eukaryotic proteins expressed in Escherichia coli: An improved thrombin cleavage and purification procedure of fusion proteins with glutathione S-transferase. Anal. Biochem. 192: 262-267.

Guan, K., R.S. Haun, S.J. Watson, R.L. Geahlen, and J.E. Dixon. 1990. Cloning and expression of a protein-tyrosine-phosphatase. Proc. Natl. Acad. Sci. 87: 1501-1505.

Guan, K., S.S. Broyles, and J.E. Dixon. 1991. A Tyr/Ser protein phosphatase encoded by vaccinia virus. Nature 350: 359 362.

Heintz, N., H.L. Sive, and R.G. Roeder. 1983. Regulation of human histone gene expression: Kinetics of accumulation and changes in the rate of synthesis and in the half-lives of individual histone mRNAs during the HeLa cell cycle. Mol. Cell. Biol. 3: 539-550.

Hunter, T. and J. Pines. 1991. Cyclins and cancer. Cell 66: $1071-1074$.

Kakizuka, A., N. Kitamura, and S. Nakanishi. 1988. Localization of DNA sequences governing alternative mRNA production of rat kininogen genes. J. Biol. Chem. 263: 3884-3892.

Kakizuka, A., W.H. Miller, Jr., K. Umesono, R.P. Warrell Jr., S.R. Frankel, V.V.V.S. Murty, E. Dmitrovsky, and R.M. Evans. 1991. Chromosomal translocation $t(15 ; 17)$ in human acute promyelocytic leukemia fuses $\operatorname{RAR} \alpha$ with a novel putative transcription factor, PML. Cell 66: 663-674.

Kandel, E.R. and J.H. Schwartz. 1985. Principles of neural science, 2nd ed. Elsevier, New York.

Krek, W. and E.A. Nigg. 1991. Mutations of p34 ${ }^{\text {cde2 } 2}$ phosphorylation sites induce premature mitotic events in HeLa cells: Evidence for a double block to p34 ${ }^{\text {cdc } 2}$ kinase activation in vertebrates. EMBO /. 10: 33.31-3341.

Kruijer, W., J.A. Cooper, T. Hunter, and I.M. Verma. 1984. Platelet-derived growth factor induces rapid but transient expression of the c-fos gene and protein. Nature 312: 711-716.

Kumagai, A. and W.G. Dunphy. 1991. The cde25 protein controls tyrosine dephosphorylation of the cdc2 protein in a cell-free system. Cell 64: 903-914.

Lee, M.G. and P. Nurse. 1987. Complementation used to clone a human homologue of the fission yeast cell cycle control gene cdc2. Nature 327: 31-35.

Lee, M.G., C.J. Norbury, N.K. Spurr, and P. Nurse. 1988. Regulated expression and phosphorylation of a possible mammalian cell-cycle control protein. Nature 333: 676-679.

Lundgren, K., N. Walworth, R. Booher, M. Dembski, M. Kirschner, and D. Beach. 1991. mikl and weel cooperate in the inhibitory tyrosine phosphorylation of cdc2. Cell 64: 11111122.

Masui, Y. and C.L. Markert. 1971. J. Exp. Zool. 177: 129-146. Cytoplasmic control of nuclear behavior during meiotic maturation of frog oocytes.

Middlemas, D.S., R.A. Lindberg, and T. Hunter. 1991. trkB, a neural receptor protein-tyrosine kinase: Evidence for a fulllength and two truncated receptors. Mol. Cell. Biol. 11: 143153.

Millar, J.B.A., J. Blevitt, L. Gerace, K. Sadhu, C. Featherstone, and P. Russell. 1991. p55 $5^{\mathrm{CDC} 25}$ is a nuclear protein required for the initiation of mitosis in human cells. Proc. Natl. Acad. Sci. 88: 10500-10504.

Moreno, S. and P. Nurse. 1991. Clues to action of cdc25 protein. Nature 351: 194

Moreno, S., P. Nurse, and P. Russell. 1990. Regulation of mito- sis by cyclic accumulation of $\mathrm{p} 80^{\operatorname{cdc} 25}$ mitotic inducer in fission yeast. Nature 344: 549-555.

Moreno, S., A. Klar, and P. Nurse. 1991. Molecular genetic analysis of fission yeast Schizosaccharomyces pombe. Methods Enzymol. 194: 795-826.

Müllner, E.W. and L.C. Kühn. 1988. A stem-loop in the 3' untranslated region mediates iron-dependent regulation of transferrin receptor mRNA stability in the cytoplasm. Cell 53: 815-825.

Nagata, A., M. Igarashi, S. Jinno, K. Suto, and H. Okayama. 1991. An Additional homolog of the fission yeast $c d c 25^{+}$ gene occurs in humans and is highly expressed in some cancer cells. New Biologist 3: 959-968.

Norbury, C., J. Blow, and P. Nurse. 1991. Regulatory phosphorylation of the $\mathrm{p} 34^{\text {cdc2 }}$ protein kinase in vertebrates. $E M B O$ I. 10: 3321-3329.

Nurse, P. 1990. Universal control mechanism regulating onset of M-phase. Nature 344: 503-508.

Nurse, $P$. and $Y$. Bissett. 1981. Gene required in $G_{1}$ for commitment to cell cycle and in $G_{2}$ for control of mitosis in fission yeast. Nature 292: $558-560$.

Pachter, J.S., T.J. Yen, and D.W. Cleveland. 1987. Autoregulation of tubulin expression is achieved through specific degradation of polysomal tubulin mRNAs. Cell 51: 283-292.

Pines, J. and T. Hunter. 1990. p34 cde2: The S and M kinase? New Biologist 2: 389-401.

. 1991. Cyclin-dependent kinases: A new cell cycle motif? Trends Cell Biol. 1: 117-121.

Reed, S.I. 1980. The selection of $S$. cerevisiae mutants defective in the start event of cell division. Genetics 95: 561-577.

1991. G1-specific cyclins: In search of an S-phase-promoting factor. Trends Genet. 7: 95-99.

Roberts, A.B. and M.B. Sporn. 1984. Cellular biology and biochemistry of the retinoids. In The retinoids /ed. M.B. Sporn, A.B. Roberts, and D.S. Goodman), vol. 2, pp. 209-286. Academic Press, San Diego, CA.

Russell, P. and P. Nurse. 1986. $c d c 25^{+}$functions as an inducer in the mitotic control of fission yeast. Cell 45: 145-153.

_- 1987. Negative regulation of mitsois by wee $1^{\text {t, a gene }}$ encoding a protein kinase homolog. Cell 49: 559-567.

Russell, P., S. Moreno, and S.I. Reed. 1989. Conservation of mitotic controls in fission and budding yeasts. Cell 57: 295303.

Sadhu, K., S.I. Reed, H. Richardson, and P. Russell. 1990. Human homolog of fission yeast cdc 25 mitotic inducer is predominantly expressed in $\mathrm{G}_{2}$. Proc. Natl. Acad. Sci. 87: 5139 5143.

Sambrook, J., E. Fritsch, and T. Maniatis. 1989. Molecular cloning: A laboratory manual. Cold Spring Harbor Laboratory. Cold Spring Harbor, New York.

Shyu, A.-B., M.E. Greenberg, and J.G. Belasco. 1989. The c-fos transcript is targeted for rapid decay by two distinct mRNA degradation pathways. Genes \& Dev. 3: 60-72.

Song, S. and C.-H. Siu. 1989. Retinoic acid regulation of the expression of retinoic acid receptors in wild-type and mutant embryonal carcinoma cells. FEBS Lett. 256: 51-54.

Stein, G.S. and J.L. Stein. 1989. Cell synchronization. In Cell growth and division: A practical approach (ed. R. Baserga), pp. 133-137. IRL Press, Oxford/New York/Tokyo.

Strausfeld, U., J.C. Labbé, D. Fesquet, J.C. Cavadore, A. Picard, K. Sadhu, P. Russell, and M. Dorée. 1991. Dephosphorylation and activation of a $334^{\text {cdc2 }} /$ cyclin $\mathrm{B}$ complex in vitro by human CDC25 protein. Nature 351: 242-245.

Treisman, R. 1985. Transient accumulation of c-fos RNA following serum stimulation requires a conserved 5 ' element and c-fos 3' sequences. Cell 42: 889-902. 


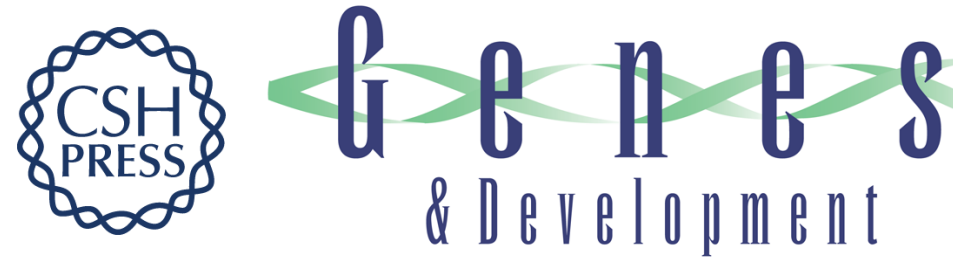

\section{A mouse cdc25 homolog is differentially and developmentally expressed.}

A Kakizuka, B Sebastian, U Borgmeyer, et al.

Genes Dev. 1992, 6:

Access the most recent version at doi:10.1101/gad.6.4.578

References This article cites 54 articles, 13 of which can be accessed free at:

http://genesdev.cshlp.org/content/6/4/578.full.html\#ref-list-1

License

Email Alerting

Service

Receive free email alerts when new articles cite this article - sign up in the box at the top right corner of the article or click here.

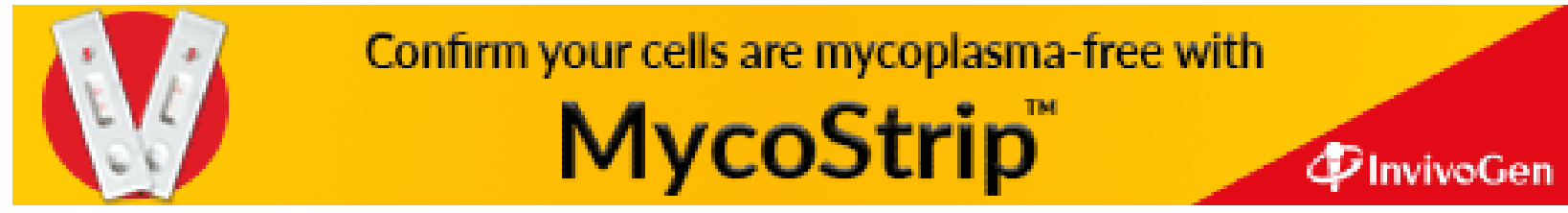

